OPEN ACCESS

Edited by:

Benjamin Gourion, UMR 2594 Laboratoire Interactions

Plantes-Microorganismes (LIPM),

France

Reviewed by:

Emanuele G. Biondi,

UMR7283 Laboratoire de Chimie

Bactérienne (LCB), France

Raphael Ledermann

University of Oxford, United Kingdom

*Correspondence:

Chi-Te Liu

chiteliu@ntu.edu.tw

Specialty section:

This article was submitted to

Plant Microbe Interactions,

a section of the journal

Frontiers in Microbiology

Received: 08 May 2019 Accepted: 07 October 2019 Published: 24 October 2019

Citation:

Chien H-L, Huang W-Z, Tsai M-Y,

Cheng C-H and Liu C-T (2019) Overexpression of the Chromosome

Partitioning Gene parA

in Azorhizobium caulinodans ORS571

Alters the Bacteroid Morphotype

in Sesbania rostrata Stem Nodules.

Front. Microbiol. 10:2422.

doi: 10.3389/fmicb.2019.02422

\section{Overexpression of the Chromosome} Partitioning Gene parA in Azorhizobium caulinodans ORS571 Alters the Bacteroid Morphotype in Sesbania rostrata Stem Nodules

\author{
Hsiao-Lin Chien', Wan-Zhen Huang ${ }^{1}$, Ming-Yen Tsai', Chiung-Hsiang Cheng ${ }^{2}$ and \\ Chi-Te Liu',3*
}

${ }^{1}$ Institute of Biotechnology, National Taiwan University, Taipei, Taiwan, ${ }^{2}$ Institute of Molecular and Comparative Pathobiology, School of Veterinary Medicine, National Taiwan University, Taipei, Taiwan, ${ }^{3}$ Agricultural Biotechnology Research Center,

Academia Sinica, Taipei, Taiwan

Azorhizobium caulinodans ORS571 is a diazotroph that forms $\mathrm{N}_{2}$-fixing nodules on the roots and stems of the tropical legume Sesbania rostrata. Deletion of the parA gene of this bacterium results in cell cycle defects, pleiomorphic cell shape, and formation of immature stem nodules on its host plant. In this study, we constructed a parA overexpression mutant (PnptII-parA) to complement a previous study and provide new insights into bacteroid formation. We found that overproduction of ParA did not affect growth, cell morphology, chromosome partitioning, or vegetative nitrogen fixation in the free-living state. Under symbiosis, however, distinctive features, such as a single swollen bacteroid in one symbiosome, relatively narrow symbiosome space, and polyploid cells were observed. The morphotype of the PnptII-parA bacteroid is reminiscent of terminal differentiation in some IRLC indeterminate nodules, but $S$. rostrata is not thought to produce the NCR peptides that induce terminal differentiation in rhizobia. In addition, the transcript patterns of many symbiosis-related genes elicited by PnptI-parA were different from those elicited by the wild type. Accordingly, we propose that the particular symbiosome formation in Pnptll-parA stem-nodules is due to cell cycle disruption caused by excess ParA protein in the symbiotic cells during nodulation.

Keywords: chromosome partitioning, nitrogen fixation, bacteroid formation, nodule development, cell cycle, plant defense

\section{INTRODUCTION}

Nodule formation in plants of the Fabaceae or Leguminosae family can be classified as determinate or indeterminate; the major difference between these types is the presence or absence of an active meristem in the fully developed organ (Hirsch, 1992; Sprent, 2007). During nodule development, rhizobia are released from infection threads, engulfed by plant-derived symbiosome membranes via endocytosis and maintained in the infected plant cells. Subsequently, the rhizobia undergo cellular differentiation to form nitrogen-fixing bacteroids (Tautz, 1992; Jones et al., 2007; Gibson et al., 2008; Downie, 2014). During the bacteroid formation process, not only cellular structure but also gene 
expression and metabolic activities are comprehensively changed to meet the needs of nitrogen fixation and adapt to the cellular environment of the nodule (Kereszt et al., 2011).

The morphotypes of the bacteroids within the nodules can be classified into swollen and non-swollen, which are mainly determined by the host legume clade rather than by the nodule type (Oono and Denison, 2010; Van De Velde et al., 2010; Kereszt et al., 2011). In some determinate nodules, such as those of Glycine, Phaseolus, Vigna and Lotus, the bacteroids are comparable in both shape and size to the corresponding free-living bacteria (i.e., the bacteroids are nonswollen). In other types of determinate nodules, such as those of Arachis and Aeschynomene (Dalbergoid clade legumes), the bacteroids are swollen. In some indeterminate nodules, such as those of Cicer and Glycyrrhiza, which belong to Inverted Repeat Lacking Clade (IRLC), non-swollen bacteroids are formed(Montiel et al., 2016). In contrast, in other IRLC legume, rhizobia form highly elongated or branched cells (i.e., swollen bacteroids) in indeterminate nodules, such as those of Medicago, Pisum, Trifolium or Vicia. The features of such bacteroids are cell enlargement, genome amplification (endoreduplication) and membrane permeabilization (Mergaert et al., 2006). Because these polyploid bacteroids lose their ability to resume growth, this type of cellular process is also called terminal bacteroid differentiation (TBD); the resulting bacteroids are proposed to be more effective in nitrogen fixation than the reversibly differentiated, reproductive bacteroids (Oono and Denison, 2010). It has been considered that host legumes have developed several strategies to control and dominate their endosymbiotic rhizobia. TBD is now known to be triggered by plant factors that show similarities to defensin-like innate immunity factors, designated as nodulespecific cysteine-rich (NCR) peptides (Mergaert et al., 2006; Wang et al., 2010).

Sesbania rostrata is a semiaquatic annual legume that originates from West Africa. It has been classified as a member of the Papilionoid subfamily and Robinioid clade (Sprent, 2007). S. rostrata can form nitrogen-fixing nodules at both the adventitious root primordia (stem nodules) and the bases of lateral roots (root nodules) with its microsymbiont Azorhizobium caulinodans (Ndoye et al., 1994). The mature stem or root nodules of $S$. rostrata are considered to be of the determinate type. However, the nature of nodule development is heterogeneous, and the early stages in $S$. rostrata also resemble those of indeterminate nodules, such as the process of proximal-distal differentiation and the place of origin (middle-inner cortex) (Ndoye et al., 1994; Goormachtig et al., 1997).

In bacteria, the process of chromosome partitioning involves the separation and positioning of daughter chromosomes in each cell cycle (Hiraga, 1993). Accurate distribution of the daughter chromosomes at cell division is essential to ensure that each cell receives a complete copy of the genome (Gordon and Wright, 2000). The best characterized family of genes that play a specific role in chromosome segregation is referred to as the parAB family, members of which encode ParA and ParB proteins (Williams and Thomas, 1992; Hiraga, 1993; Ireton et al., 1994; Gordon et al., 1997; Sharpe and Errington, 1998;
Hiraga, 2000; Bignell and Thomas, 2001). This process is very efficient and precise, and cells lacking chromosomes are very rarely produced (Hiraga, 2000). Deletion or overexpression of par genes affects chromosome partitioning in many bacteria, such as Bacillus subtilis, Caulobacter crescentus, Pseudomonas aeruginosa, and Myxococcus xanthus, resulting in accumulation of anucleate cells, late cell growth and abnormal cell morphology (Easter and Gober, 2002; Ogura et al., 2003; Lee and Grossman, 2006; Lasocki et al., 2007; Kusiak et al., 2011; Mierzejewska and JaguraBurdzy, 2012; Bartosik et al., 2014; Iniesta, 2014). In addition, mutations in the par system mutations affect DNA replication (Murray and Errington, 2008), cytokinesis (Mohl et al., 2001), sporulation (Ireton et al., 1994), and motility (Lasocki et al., 2007; Bartosik et al., 2009).

In our previous study, we found that the null mutant of a chromosome partitioning gene (parA) (genomelocus tag AZC_4711 [accession number AP009384], region 5360130.0.5360978 [DDBJ/EMBL/GenBank databases]) of A. caulinodans ORS571 (strain ORS571- $\triangle$ parA, designated $\Delta$ parA) had an altered cell cycle and formed elongated or branched cells with higher nucleic acid contents (polyploidy) (Liu et al., 2011). We assumed that the $\Delta$ parA cells had already differentiated prior to invading their host plant. When $S$. rostrata was inoculated with $\triangle p a r A$, immature stem nodules with varying degrees of maturity were generated. The transcript level of the parA was inversely correlated with the maturity of the nodule, and the transcript was absent in fully mature bacteroids. Accordingly, we propose that the parA gene not only plays a crucial role in the partitioning of chromosomes but also participates in the bacteroid formation process in $S$. rostrata stem nodules.

Despite many investigations of the roles of the ParAB proteins in various bacteria, very little is known about how the chromosome partitioning system is involved in bacteroid development and nitrogen fixation during rhizobium-legume symbiosis. The aim of this study was to elucidate the effects of ParA overproduction in A. caulinodans ORS571 under free-living conditions and during symbiosis to complement the previously reported studies of the parA null mutant. Thus, we constructed a PnptII-parA mutant strain harboring a plasmid expressing parA from a strong constitutive promoter (PnptII), to analyze the cell morphology, viability and symbiotic features of A. caulinodans ORS571 under parA overexpression.

\section{MATERIALS AND METHODS}

\section{Biological Materials}

The bacterial strains and plasmids used in this study are listed in Table 1. Derivatives of A. caulinodans strain ORS571 (Dreyfus et al., 1988) were grown at $37^{\circ} \mathrm{C}$ in TY medium (Beringer, 1974) or L2-N medium with appropriate antibiotics. L2-N medium is a synthetic nitrogen-deficient medium modified from LO medium (Dreyfus et al., 1983). Escherichia coli strains were grown in LB broth at $37^{\circ} \mathrm{C}$. Antibiotics were used when appropriate at the following concentrations: nalidixic acid $25 \mu \mathrm{g} / \mathrm{ml}$, kanamycin $50 \mu \mathrm{g} / \mathrm{ml}$, ampicillin $100 \mu \mathrm{g} / \mathrm{ml}$, and tetracycline $20 \mu \mathrm{g} / \mathrm{ml}$. 
TABLE 1 | Bacterial strains and plasmids used in this study.

\begin{tabular}{|c|c|c|}
\hline Strains and plasmids & Description or relevant phenotype ${ }^{a}$ & References \\
\hline \multicolumn{3}{|l|}{ Escherichia coli } \\
\hline $\mathrm{DH} 5 \alpha$ & 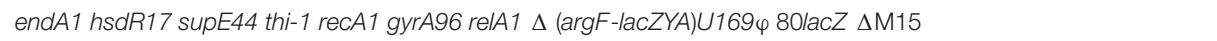 & Invitrogen \\
\hline S17-1 & RP4 tra region, mobilizer strain, for conjugation, $\mathrm{Sp}^{r}$ & Simon et al., 1983 \\
\hline \multicolumn{3}{|c|}{ Azorhizobium caulinodans } \\
\hline ORS571 & Wild-type, $\mathrm{Nx}^{r}$ & Dreyfus et al., 1988 \\
\hline ORS571- $\Delta$ parA & Null mutation of a putative chromosome partitioning gene (parA), Nx & Liu et al., 2011 \\
\hline ORS571-PnptII-parA & Constitutive expression of parA gene driven by a nptll promoter, $\mathrm{Nx}^{r}, \mathrm{Ap}^{r}, \mathrm{TC}^{r}$ & This study \\
\hline \multicolumn{3}{|l|}{ Plasmids } \\
\hline nptIl:parA:pFAJ1708 & pFAJ1708 with 940-bp BamHI/Kpnl fragment, transcription of parA driven by a constitutive npt/l promoter, $\mathrm{Ap}^{r}, \mathrm{Tc}^{r}$ & This study \\
\hline pFAJ1708 & Broad-host-range plasmid containing npt/l promoter, $\mathrm{Ap}^{r}, \mathrm{TC}^{r}$ & Dombrecht et al., 2001 \\
\hline
\end{tabular}

a Abbreviations: $N x^{r}$, nalidixic acid $25 \mu \mathrm{g} / \mathrm{ml} ; \mathrm{Km}^{r}$, kanamycin $50 \mu \mathrm{g} / \mathrm{ml}$; Ap ${ }^{r}$, ampicillin $100 \mu \mathrm{g} / \mathrm{ml}$; TC ${ }^{r}$, tetracycline $20 \mu \mathrm{g} / \mathrm{ml}$.

S. rostrata seeds were treated with concentrated sulfuric acid for $8 \mathrm{~min}$ and then placed under dripping water for an hour to induce rapid and uniform germination. Seedlings were grown for 3 weeks before inoculation at $35^{\circ} \mathrm{C}$ under a 24 -h light regime by light-emitting diode (LED) illumination (Maxima 5000 SLD 5100 , Neotroni, Taiwan) at an intensity of 30,000 lux $(0.5 \mathrm{mmol}$ photons $\left.\mathrm{m}^{-2} \mathrm{~s}^{-1}\right)$. Three-week-old plants were inoculated with the desired azorhizobial strains at the mid-exponential phase $\left(\sim 5 \times 10^{8}\right.$ cells per $\left.\mathrm{ml}\right)$ between the first and second stem internodes, where stem nodule development is synchronized (Donald et al., 1986). All developmental nodulation tests were performed in at least in triplicate.

\section{Construction of parA Overexpression Mutant}

To construct a plasmid that expresses the parA gene constitutively under the control of the nptII promoter, the parA gene was amplified by PCR with the primers parA-F and parA-R, and the resulting DNA fragment (943 bp) was digested with BamHI and KpnI for cloning in the replicative broad-host-range plasmid pFAJ1708 (Dombrecht et al., 2001). The resulting plasmid was designated nptII-parA:pFAJ1708 (Supplementary Figure S1). All the PCR primer pairs used for plasmid construction are shown in Table 2. The parA sequence in the construct was verified by subsequent sequencing. The resulting plasmid was conjugated into A. caulinodans ORS571 via $E$. coli S17-1 ( $\lambda$ pir). The resulting strain, ORS571-PnptIIparA (hereafter abbreviated to PnptII-parA), was selected by tetracycline and ampicillin resistance.

\section{Western Blot Analysis}

Mid-exponential-phase bacterial strains were harvested and then homogenized by French press (Avestin EmulsiFlex-C3, Canada) at $18,000 \mathrm{psi}$. The soluble proteins $(10 \mu \mathrm{g})$ were analyzed with $12.5 \%$ SDS-PAGE and subsequently analyzed with Western blot (Towbin et al., 1979). The rabbit anti-AzoParA IgG (LTK BioLaboratories, Taiwan) was used as the primary antibody for ParA detection. The horseradish peroxidase (HRP)conjugated goat anti-rabbit IgG (Millipore) was used as a secondary antibody. Signals were detected by Western HRP and
AP chemiluminescent substrates (Millipore) and visualized by BioSpectrum 510 (UVP).

To quantify the endogenous ParA proteins in A. caulinodans derivatives, Western blot signals were measured using ImageJ as described previously (Schneider et al., 2012).

\section{Acetylene Reduction Assay of Free-Living Bacteria and Stem Nodules}

The biological $\mathrm{N}_{2}$ fixation (BNF) ability of free-living azorhizobial derivatives and stem-nodules was determined by acetylene reduction assay (ARA) (Dilworth, 1966). To assess the BNF ability of free-living bacteria, azorhizobial cells were collected at mid-exponential phase in TY broth by centrifugation, and the cells were washed twice with $\mathrm{L} 2-\mathrm{N}$ medium and suspended in L2-N medium to an optical density at $600 \mathrm{~nm}\left(\mathrm{OD}_{600}\right)$ of 0.1 . In the following incubation, $50 \mathrm{ml}$ aliquots of culture were transferred into $250 \mathrm{ml}$ Erlenmeyer flasks sealed with sterile rubber septa. The gas phase in the flask was replaced with $\mathrm{N}_{2}$ gas containing $15 \%$ air $\left(\sim 3 \% \mathrm{O}_{2}\right)$ and $10 \%$ $\mathrm{C}_{2} \mathrm{H}_{2}$ and incubated at $37^{\circ} \mathrm{C}$ with shaking at $200 \mathrm{rpm}$. After incubation for $15 \mathrm{~h}, 0.5 \mathrm{ml}$ gas samples were taken from the flask, and the ethylene concentration was assayed using a gas chromatograph (HITACHI, G-3000) equipped with a HayeSep T80/100 packed column (Supelco) and a flame ionization detector (Suzuki et al., 2007). The $\mathrm{OD}_{600}$ of each sample was measured immediately following the gas sampling.

Ten stem-nodules were excised from individual plants and placed into $15-\mathrm{ml}$ vials sealed with a butyl rubber septum. The air in the vials was replaced with $10 \%(\mathrm{vol} / \mathrm{vol}) \mathrm{C}_{2} \mathrm{H}_{2}$, and the vials were incubated at $37^{\circ} \mathrm{C}$ for an hour. After incubation, $0.5 \mathrm{ml}$ of gas was sampled from each vial, and the concentrations of acetylene and ethylene were measured.

\section{Optical and Electron Microscopic Analyses}

For observation of free-living bacteria, each bacterial strain was grown in TY medium until the mid-exponential phase (around optical density at $600 \mathrm{~nm}\left[\mathrm{OD}_{600}\right]$ of 0.5 ). Broth cultures were stained with 4,6-diamidino-2-phenylindole (DAPI; SigmaAldrich, 28718-90-3) at $10 \mu \mathrm{g} / \mathrm{ml}$ for $5 \mathrm{~min}$ at $25^{\circ} \mathrm{C}$ according to the method reported by Rowe and Summers (1999). Cells in 
TABLE 2 | Primers used in this study.

\begin{tabular}{|c|c|c|c|c|c|}
\hline Gene name & Locus & Forward & Reverse & Product size (bp) & References \\
\hline parA-BamHI-Fa & & GGGATCCCGACCGCGAAGGGGAAAAC & & 942 & This study \\
\hline \multicolumn{6}{|c|}{ Azorhizobium caulinodans ORS571 quantitative RT-PCR } \\
\hline $16 S$ & & ACGGATTTCTTCCAGCAATG & ACCGGCAGTCCCTITAGAGT & 130 & Akiba et al., 2010 \\
\hline nodD & Azc_3792 & AACCCCCGATCTGGGTAAT & CATCATTTGGGATGCATGG & 64 & This study \\
\hline nodZ & Azc_3811 & CACAATTAGGTGATCATAGAACTCG & TTGCTGTCTCATGTGGTGCT & 64 & This study \\
\hline nodB & Azc_3817 & GAGCGCCGCTAATGTCTG & CCAGATGAAGCTGCGATG & 60 & This study \\
\hline nolk & Azc_3850 & ATCGCATCTTCTGCCTGC & СTCACACTITCGCTACCACA & 69 & This study \\
\hline nifD & Azc_1040 & CGCACATCGCCAACACCA & ACCGTCCGCCAGATAGGC & 68 & This study \\
\hline nifH2 & Azc_1041 & GACCTGGCTCTCGTCCAC & CACTATCGCAACCTCGCTGA & 135 & This study \\
\hline nifA & Azc_1049 & ССТTCTCATGGCCGAACA & CCTTCGTGAAGGTGAACTGC & 72 & This study \\
\hline bacA & Azc_4674 & GAACTCGGTCAGTCCCTCG & CGTTCCCGTGCCCTTCT & 98 & This study \\
\hline oac3 & Azc_1831 & TGGACTTCGCCTGCTCCT & CCTGCGTATTTCCTCGCCC & 95 & This study \\
\hline oac2 & Azc_1832 & GTGGAATGTCCGCTCGAA & TCACCACCGCCGAGTATC & 146 & This study \\
\hline oac1 & Azc_1833 & AGGCGGAATAGGGCGAAT & CACCAACATCAACGGCAC & 188 & This study \\
\hline$d n a A$ & Azc_1047 & TCGGCGGTCAGATACACC & CGTTGGCCTCGGTAAGAC & 87 & This study \\
\hline fts $Z$ & Azc_4564 & CGACGCCAACATCATCCTC & ATCTGCTCGGGAACCACC & 108 & This study \\
\hline parA & Azc_4711 & ССТCTCCATCCACGGCATC & CGCACATCCTCCACCACC & 78 & This study \\
\hline parB & Azc_4712 & CCAAGGTCATCGGCAAGAG & GGCAGTTCAGCAGGCGG & 61 & This study \\
\hline \multicolumn{6}{|c|}{ Sesbania rostrata quantitative RT-PCR } \\
\hline Srubi & & GATIITGTGAAGACCTTGACGGG & CACAGACCCATTACACATCCACAAG & 300 & Corich et al., 1998 \\
\hline SrPl1 & & TGGCAATTCTTGTGCCTAGTG & TGCAATGCTCAAACCCAGA & 134 & Lievens et al., 2004 \\
\hline
\end{tabular}

${ }^{a}$ The BamHI site is underlined. ${ }^{b}$ The $\mathrm{Kpnl}$ site is underlined.

suspension were mounted and examined by light microscopy (BX51, Olympus, Japan) under a bright or fluorescent field by use of the U-MWU2 filter set with UV excitation (excitation spectrum, 330 to $385 \mathrm{~nm}$; emission spectrum, $420 \mathrm{~nm}$; Olympus, Japan).

Stem-nodules were harvested at 7 days post inoculation (dpi) and fixed in FAA solution (formalin: acetic acid: $50 \%$ alcohol $=1$ : 1: 18) overnight for microscopic analysis. FAA-fixed nodules were embedded in 5\% (w/v) agar and sectioned using a microslicer (DTK-1000, Dosaka, EM, Japan). Sliced sections were stained with $0.05 \%$ toluidine blue O (TBO) (O'brien et al., 1964) and observed using light microscopy as described above.

For transmission electron microscopy (TEM) analysis, $7 \mathrm{dpi}$ stem nodule samples were fixed in $2.5 \%(\mathrm{w} / \mathrm{v})$ glutaraldehyde at $4^{\circ} \mathrm{C}$ and then shaken overnight. The fixed nodules were washed with $0.1 \mathrm{M}$ sodium phosphate buffer $(\mathrm{pH}=7.2)$, post-fixed in $1 \%$ osmium tetroxide $(\mathrm{w} / \mathrm{v})$, dehydrated in an ethanol series, and then embedded in Spurr's resin (Electron Microscopy Sciences, United States) for conventional TEM as described previously (Spurr, 1969). Semithin sections $(500 \mathrm{~nm})$ and ultrathin sections $(70 \mathrm{~nm})$ were taken from the resin-embedded samples using a Reichert-Jung Ultracut
E ultramicrotome (Reichert-Jung, United States). The ultrathin sections for conventional TEM were collected on Pioloformcoated copper grids and stained with uranyl acetate $(10 \mathrm{~min})$ and lead citrate ( $5 \mathrm{~min}$ ) before being viewed with a JEOL JEM-1400 transmission electron microscope (JEOL Ltd., Japan).

\section{Bacteroid Isolation From S. rostrata Stem-Nodules}

Bacteroids were isolated from 5 dpi stem nodules of S. rostrata by a method modified from that described by Tsukada et al. (2009). Stem-nodules (5 g) were homogenized with $0.5 \mathrm{~g}$ of polyvinylpyrrolidone (Sigma-Aldrich, 9003-39-8) and $2 \mathrm{ml}$ of Mg-phosphate buffer $\left(2.5 \mathrm{mM} \mathrm{MgCl}_{2}, 50 \mathrm{mM}\right.$ potassium phosphate, $\mathrm{pH}$ 6.8) using a cold mortar and pestle. The paste was diluted with $10 \mathrm{ml}$ ice-cold $\mathrm{Mg}$-phosphate buffer and passed through a $40 \mu \mathrm{m}$ filter (BD Biosciences) to collect the filtrate. The filtrate was centrifuged at $500 \mathrm{~g}$ for $2 \mathrm{~min}$ at $4^{\circ} \mathrm{C}$ to obtain the supernatant and remove the plant cell materials, and this step was repeated several times until no obvious green pellet remained. The supernatant was then centrifuged at 5,000 $\times g$ for $5 \mathrm{~min}$ at $4^{\circ} \mathrm{C}$ to collect the bacteroids. 


\section{Flow Cytometric Analyses}

Cultured bacteria and bacteroids were fixed in $90 \%$ ethanol overnight at $-20^{\circ} \mathrm{C}$. Cells were then washed twice with PBS followed by centrifugation for $2 \mathrm{~min}$ at $1,200 \times g$. Pelleted cells were stained with propidium iodide (PI)-RNase staining buffer solution (BD Biosciences, 550825 ) for $30 \mathrm{~min}$ at room temperature. For each flow cytometry experiment, the DNA content was measured in a population of 20,000 cells with a Cytomics FC500 analyzer (Beckman Coulter Ltd.). Data analysis was performed with CXP software (Beckman Coulter Ltd.) (Wake and Errington, 1995).

\section{RNA Isolation and Purification}

Bacteria were grown in TY medium until the optical density of the culture at $600 \mathrm{~nm}\left[\mathrm{OD}_{600}\right]$ reached 0.5 or in $\mathrm{L} 2$ medium for $15 \mathrm{~h}$ (the detailed conditions are described in the ARA assay session) and then harvested by centrifugation. Total RNA was isolated using the RNeasy Protect Bacteria Mini Kit (Qiagen, 74104) according to the manufacturer's instructions. Plant nodule RNA was isolated from plant stem-nodules after inoculation with bacteria, at 3, 5, 7, and 10 dpi. Nodules were homogenized in liquid nitrogen with steel beads, and RNA was extracted with TRIzol Reagent. Total RNA from bacteroids was isolated from stem-nodules as follows. Stemnodules were homogenized in liquid nitrogen with a mortar and pestle, and the paste was diluted with $1 \mathrm{ml}$ ice-cold $\mathrm{Mg}$ phosphate buffer and passed through a $40 \mu \mathrm{m}$ filter (BD Biosciences) to collect the filtrate. The filtrate was centrifuged at $5,000 \times g$ for $5 \mathrm{~min}$ at $4^{\circ} \mathrm{C}$, and total RNA was extracted using TRIzol Reagent (Invitrogen, 15596018) according to the manufacturer's instructions. To collect pure bacterial RNA, total RNA was purified using the MICROBEnrich Kit (Invitrogen, AM1901) according to the manufacturer's instructions to obtain bacterial RNA. All of the above RNA samples were treated with TURBO DNase (Invitrogen, AM2238) to remove DNA contamination.

\section{Quantitative RT-PCR}

Total RNA was isolated from free-living bacteria, bacteroids or plants as described above. First-strand cDNA was synthesized from the extracted RNA $(1 \mu \mathrm{g})$ by reverse transcription (RT) using the SuperScript III First-Strand Synthesis System (Invitrogen) with the random primers (for bacteria) or oligo1218 (for plants) included in the SuperScript III First-Strand Synthesis System according to the manufacturer's instructions. The qRT-PCR was carried out with the LightCycler 480 system (Roche, Germany) and SYBR Green mix (KAPA Biosystems, United States). All primer sequences are listed in Table 2. The 16S rRNA gene was used as a reference gene for bacteria, and a ubiquitin cDNA fragment (Srubi) was used as a reference gene for the host plant to calculate the relative expression of each target gene. The data were processed with LightCycler 480 software (Version 1.5). All tests were performed at least in three independent biological replicates.

\section{RESULTS}

\section{ParA Protein Levels in A. caulinodans ORS571 Derivatives Cultivated in Either Rich (TY) or Minimal (L2-N) Medium}

We constructed a ParA-overproducing A. caulinodans ORS571 strain (PnptII-parA) harboring a plasmid that constitutively expressed the parA gene under the control of the nptII promoter (Supplementary Figure S1). Western blot analysis was performed to examine the endogenous ParA protein level in the parA mutants cultivated in either TY or L2-N broth. When the bacteria were cultivated aerobically in rich broth (TY), the ParA protein level in PnptII-parA cells was significantly elevated (3.9-fold) compared with that in the wild-type strain (ORS571) (Figure 1A). In contrast, ParA was undetectable in the $\triangle$ parA cells. When the bacteria were cultivated in minimal broth (L2-N) under microaerobic conditions, high constitutive expression of the ParA protein was detected in the PnptII-parA cells (Figure 1B). However, ParA was not detected in the ORS571 cells, indicating that the level of protein content was below the detection limits.

\section{Overproduction of ParA Did Not Affect Growth, Cell Morphology, Chromosome Partitioning, or Vegetative Nitrogen Fixation in the Free-Living State}

As shown in Figure 2A, the growth of PnptII-parA was slightly slower than that of ORS571 during the exponential phase when the bacteria were cultivated in TY broth, although the

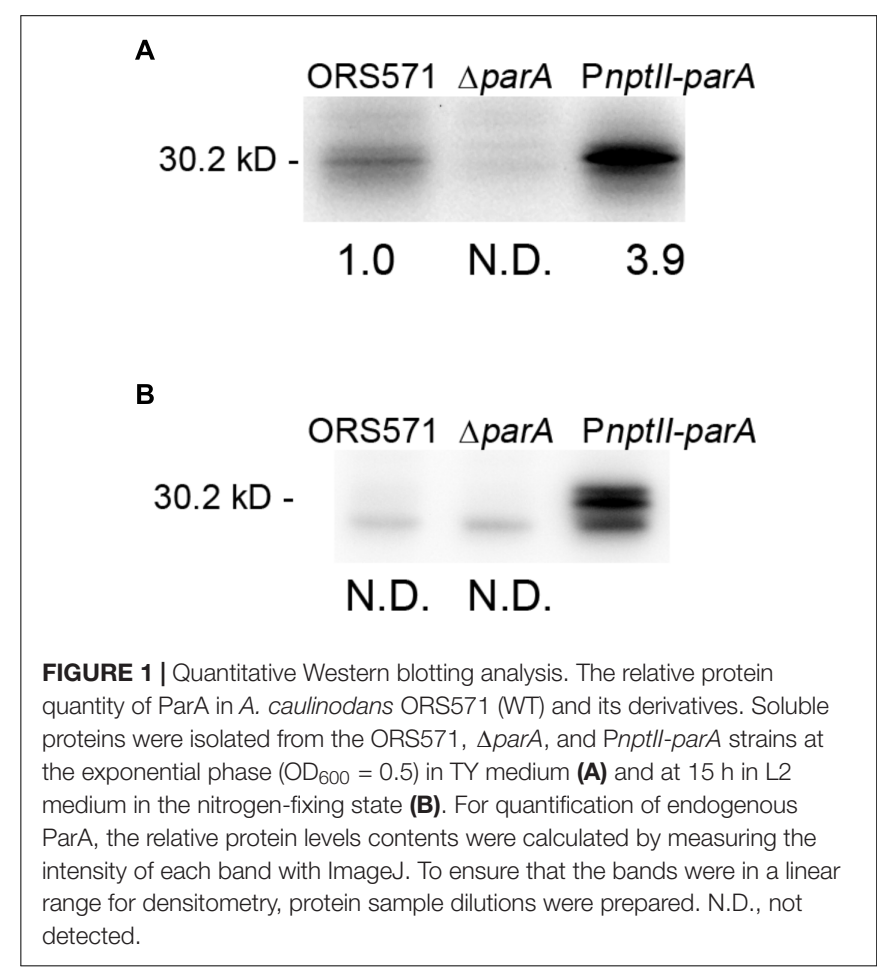




\section{A}

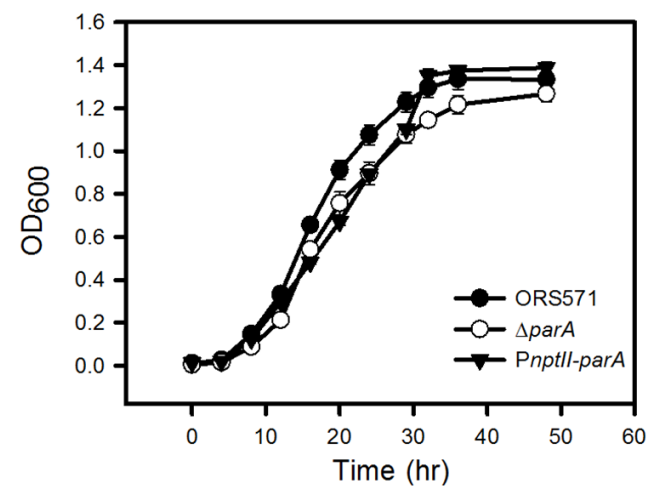

B

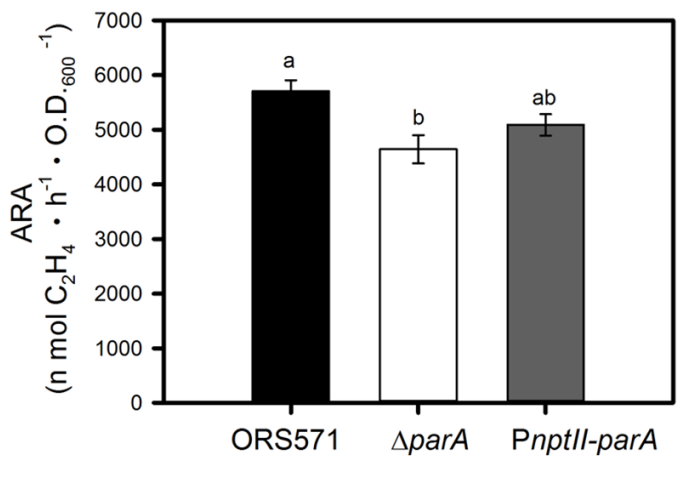

ORS571
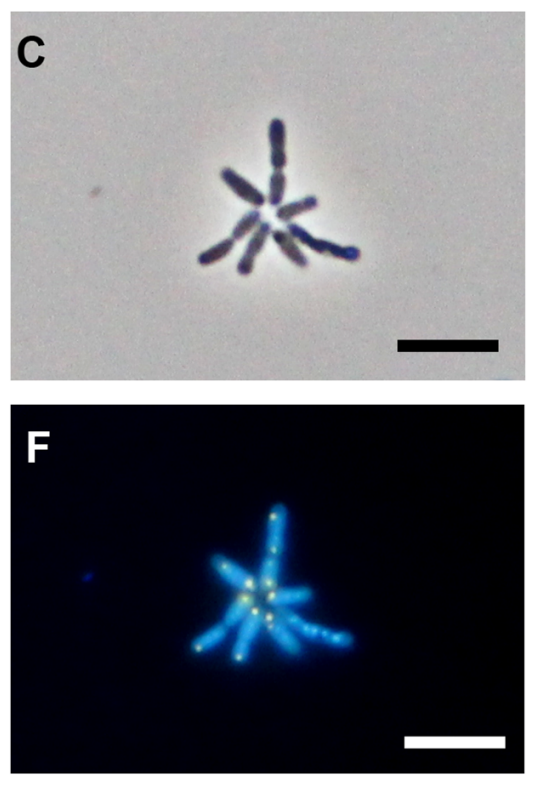

$\Delta$ parA
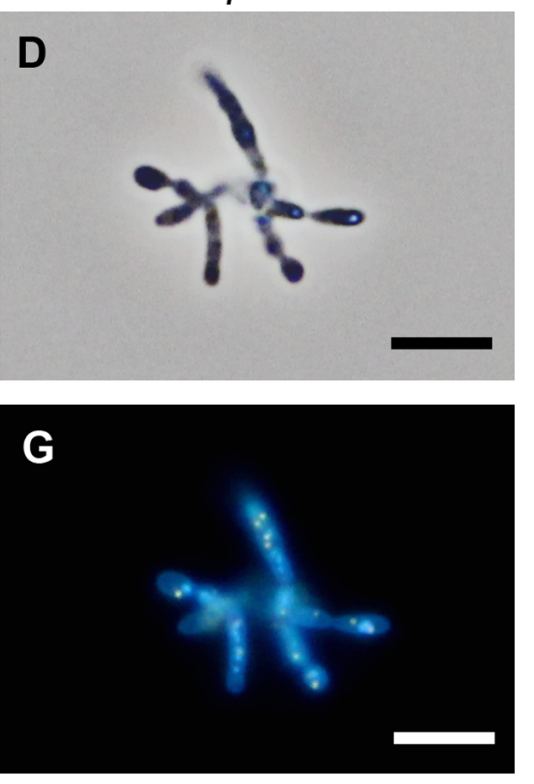

Pnptll-parA
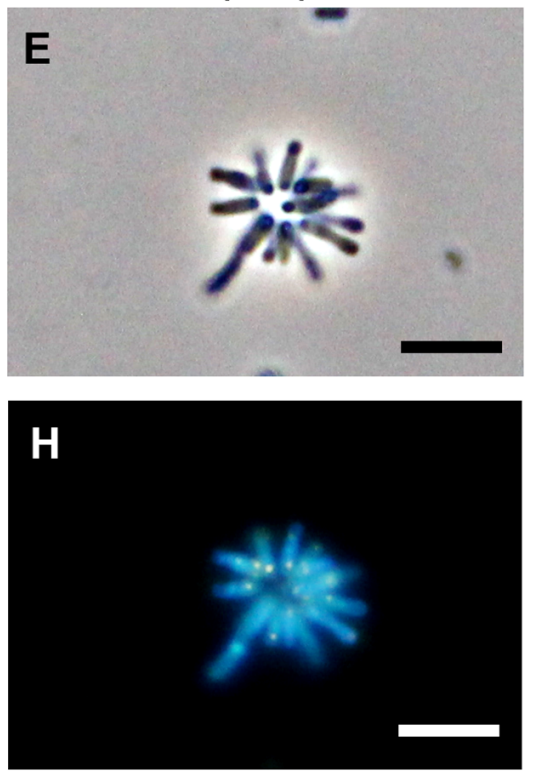
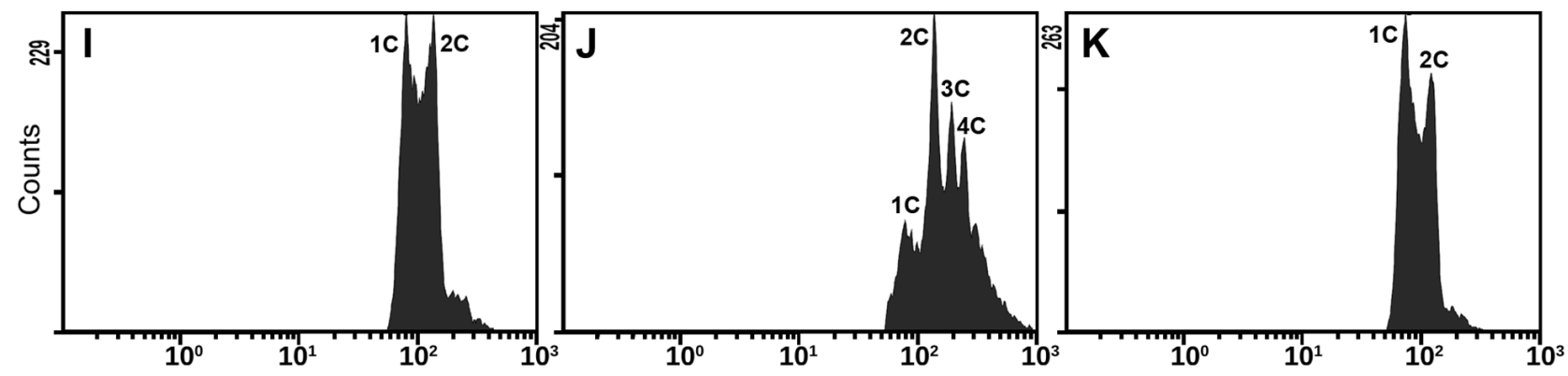

FIGURE 2 | Phenotypes of $A$. caulinodans and its derivatives in the free-living state. (A) Growth curves of $A$. caulinodans and its derivatives under free-living conditions. All the bacteria were grown at $37^{\circ} \mathrm{C}$ in $T Y$ broth. The values are the means of at least three replicates. (B) Nitrogen fixation activity of $A$. caulinodans and its derivatives under free-living conditions. All the bacteria were grown for $15 \mathrm{~h}$ at $37^{\circ} \mathrm{C}$ in synthetic nitrogen-deficient medium ( $\mathrm{L} 2-\mathrm{N}$ medium) to induce nitrogen fixation. The values are the means \pm standard deviations of three biological replicates. $P<0.05$ (post hoc analysis: Tukey). (C-H) Morphology of $A$. caulinodans derivatives under vegetative conditions. The ORS571 (C,F), $\Delta$ parA (D,G), and Pnptll-parA (E,H) strains were incubated to OD $600=0.5$ in TY broth and stained with DAPI $(10 \mu \mathrm{g} / \mathrm{ml})$. (C-E) Phase contrast image. (F-H) Fluorescent image. Scale bars $=5 \mu \mathrm{m}$. (I-K) Flow cytometry analyses showing the DNA levels contents of the cultured bacteria. Exponential-phase cultures of ORS571 (I), $\Delta$ parA (J), and PnptII-parA (K) cells were fixed and stained with propidium iodide (PI). For each histogram, the $x$ axis shows fluorescence levels, which represent the DNA levels per particle counted. The $y$ axis shows counts, which indicate the number of fluorescing particles or cells. In each experiment, 20,000 cells were analyzed. 
CFU did not differ from that of ORS571 (data not shown). The bacterial cells of PnptII-parA showed autoagglutination (rosetting), and the average length of each cell was 1.0 to $2.0 \mu \mathrm{m}$ (Figure 2E). These morphological features were indistinguishable from those of ORS571 (Figure 2C). On the other hand, the growth rate of the parA gene null mutant ( $\triangle$ parA) was reduced, which is consistent with the previous study (Liu et al., 2011). The $\triangle$ parA culture displayed large numbers of various sizes of filamentous and branched cells, and no autoagglutination was observed (Figure 2D). As shown in Figures $\mathbf{2 F - H}$, the vegetative cells of both ORS571 and PnptII-parA contained compact nucleoids at the cell poles when stained with DAPI $(4,6-$ diamidino-2-phenylindole). In contrast, the free-living $\triangle$ parA mutant cells were polyploid, suggesting dramatic defects in nucleoid partitioning (Figure 2G). We further performed flow cytometry analysis to confirm the DNA contents of the freeliving cells in the exponential phase. As shown in Figure 2K, the DNA content distribution of PnptII-parA was composed of two peaks ( $1 \mathrm{C}$ and $2 \mathrm{C}$ ), as in ORS571. On the other hand, multiple genome equivalents were observed in the $\triangle$ parA mutant cells (Figure 2J). These results are consistent with the microscopic observations. The vegetative nitrogen-fixing activity of the bacteria was determined by acetylene reduction assay (ARA), and the numeric value of the ARA was found to be comparable between PnptII-parA and ORS571 (Figure 2B), indicating that vegetative nitrogen-fixing ability is not affected by $\operatorname{par} A$ overexpression. In contrast, the ARA was significantly reduced in the $\triangle$ parA cells.

\section{Transcription of Selected Symbiotic Genes in the Free-Living State}

To verify the transcription of symbiosis-related genes in the ORS571 derivatives in the vegetative state, we determined the expression levels of selected symbiosis-related genes, including nodulation genes (nod, noe, and nol), nitrogen-fixation genes (nif/fix), cell-cycle-related genes (parA, dnaA, and ftsZ), surface polysaccharide-related genes (expA4, expA9/oac1 and $\operatorname{expA10/oac2)}$ and bacteroid differentiation related gene (bacA) in the ORS571 derivatives in the vegetative (i.e., grown in TY-rich medium under aerobic conditions) or free-living nitrogen-fixing state (i.e., grown in L2 minimal medium under microaerobic conditions). As shown in Table 3, the relative expression levels of the parA gene in PnptII-parA were considerably larger (83-fold) than those of the ORS571 in the nitrogen-fixing state. Strikingly, we noticed that the relative transcript levels of most of the target genes, especially those associated with nodulation (such as nodD and nolK), were elevated in PnptII-parA cells in the nitrogenfixing state without flavonoid addition (Table 3). It has been proven that the flavonoid naringenin could induce the expression of nodulation genes in free-living A. caulinodans cells (Tsukada et al., 2009). For verification, we added the flavonoid naringenin to the broth ( $22+\mathrm{N}$ medium) and determined the transcription levels of some nodulation-related genes (nod and noe) (detailed in Supplementary Materials). As shown in Supplementary Figure S2, the addition of naringenin significantly elevated the expression of the genes in ORS571. This result was consistent with the previous finding reported by Tsukada et al. (2009). On the other hand, we found only the expression of the nodD gene was enhanced in the vegetative PnptII-parA cells (Supplementary Figure S2). In contrast, the expression of those of the other nodulation related genes were declined. Similarly, these genes were all repressed in the $\Delta$ parA cells.

\section{parA Overexpression Caused Aberrant Stem-Nodules}

We inoculated the ORS571 derivatives onto the stems of $S$. rostrata, and all plants were grown at $35 \sim 40^{\circ} \mathrm{C}$ under a 24 $\mathrm{h}$ light regime. As shown in Figure 3J, the average size of the 14 dpi PnptII-parA stem nodules was approximately $1.8 \mathrm{~mm}$, significantly smaller than that of ORS571 $(2.49 \mathrm{~mm})$. The crosssections of the 7 dpi PnptII-parA stem nodules showed green or beige interiors (Figure 3C), whereas those of ORS571 were pink or red (Figure 3A). As shown in Figures 3F,I, some of the PnptII-parA stem-nodules appeared pale red (asterisks) or beige (arrowheads). We determined the nitrogen-fixing activity (ARA) of the stem-nodules and found that the PnptII-parA stem-nodules showed greatly reduced ARA during the entire nodulation period (Figure 3K).

In the stem-nodules of ORS571 or $\triangle$ parA, large numbers of bacteria colonized the infection centers (i.e., the dark blue regions stained by toluidine blue $\mathrm{O}$ ) (Figures $4 \mathbf{A}, \mathbf{B}, \mathbf{D}, \mathbf{E}$ ). In contrast, fewer and smaller infected cells were present in the central cortical tissues of the PnptII-parA stem-nodules (Figures 4C,F). In addition, some infection threads proliferated abnormally, forming reticulated architectures, and only a few internalized bacteria were observed in the cortical cells (Supplementary Figure S3).

In the PnptII-parA mutant-induced nodules, the symbiosome membrane closely surrounded a single pleomorphic-shaped bacteroid (Figure 4I), whereas a broad symbiosome space between the bacteroid(s) and the symbiosome membrane was observed in both the ORS571 (Figure 4G) and $\triangle$ parA infected nodules (Figure $\mathbf{4 H}$ ). We also performed flow cytometry analysis to determine the DNA contents of the bacteroids in the different stem-nodules. In the $7 \mathrm{dpi}$ stem nodules induced by the two parA mutants ( $\triangle$ parA and PnptII-parA), triploid or tetraploid (3C or $4 \mathrm{C}$ ) cells were able to be observed in the bacteroids (Figures 4K,L). On the other hand, ORS571 bacteroids were mainly haploid and diploid (1C and 2C) (Figure 4J).

\section{Expression of Symbiosis-Related Genes in Bacteroids}

To verify the symbiotic gene expression of the ORS571 derivatives in the early stages of nodulation, we detected the transcripts of certain bacterial genes related to the early stage of stemnodule development by qPCR. As shown in Table 4, the relative expression of these cell-cycle-related genes, such as parA and ftsZ, was upregulated in both $\triangle$ parA and PnptIIparA nodules, especially that of the parA gene, which was dramatically elevated in the latter. Notably, the level of $d n a A$, a key bacterial DNA replication initiation factor, was significantly increased in only the PnptII-parA nodules. We also determined 
TABLE 3 | Bacterial gene expression in the free-living state.

\begin{tabular}{|c|c|c|c|c|c|}
\hline \multirow[b]{2}{*}{ Category } & \multirow[b]{2}{*}{ Gene name } & \multicolumn{2}{|c|}{ TY medium } & \multicolumn{2}{|c|}{ L2-N medium } \\
\hline & & $\Delta p a r A / W T$ & PnptII-parA/WT & $\Delta p a r A / W T$ & PnptIl-parA/WT \\
\hline \multirow[t]{5}{*}{ nod } & nodD & $5.1 \pm 0.62 *$ & $1.02 \pm 0.23$ & $1.37 \pm 0.27$ & $5.48 \pm 0.17^{*}$ \\
\hline & noeC & $6.87 \pm 1.32^{*}$ & $0.52 \pm 0.38$ & $1.78 \pm 0.47^{*}$ & $1.84 \pm 0.63$ \\
\hline & $\operatorname{nod} Z$ & $16.29 \pm 7.20^{*}$ & $0.49 \pm 0.34$ & $0.60 \pm 0.11^{*}$ & $2.38 \pm 0.77^{*}$ \\
\hline & nodB & $11.44 \pm 1.08$ & $0.69 \pm 0.46$ & $0.58 \pm 0.11^{*}$ & $3.43 \pm 0.73^{*}$ \\
\hline & nolk & $6.58 \pm 0.34^{*}$ & $0.81 \pm 0.77$ & $2.51 \pm 0.75$ & $2.19 \pm 0.15^{*}$ \\
\hline \multirow[t]{4}{*}{ nif/fix } & nifD & $1.35 \pm 0.44$ & $0.43 \pm 0.15^{*}$ & $0.89 \pm 0.24^{*}$ & $1.89 \pm 0.18^{*}$ \\
\hline & nifH2 & $1.95 \pm 0.03$ & $0.42 \pm 0.26$ & $0.71 \pm 0.13^{*}$ & $2.47 \pm 0.06^{*}$ \\
\hline & nifA & $1.96 \pm 0.46$ & $0.96 \pm 1.14$ & $0.85 \pm 0.19^{*}$ & $0.03 \pm 0.02$ \\
\hline & fixN & $0.57 \pm 0.50$ & $0.25 \pm 0.09^{*}$ & $1.40 \pm 0.23^{*}$ & $1.33 \pm 0.06^{*}$ \\
\hline \multirow[t]{4}{*}{ Polysaccharide } & оас3/еxpA7 & $0.87 \pm 0.21$ & $0.44 \pm 0.14^{*}$ & $0.55 \pm 0.11$ & $2.68 \pm 1.13$ \\
\hline & oac2/expA10 & $0.98 \pm 0.22$ & $0.83 \pm 0.3$ & $0.44 \pm 0.12^{*}$ & $2.78 \pm 0.56^{*}$ \\
\hline & оас1/ехрA9 & $0.95 \pm 0.36$ & $1.28 \pm 0.44$ & $0.88 \pm 0.18$ & $2.50 \pm 0.16^{*}$ \\
\hline & expA4 & $2.61 \pm 2.53$ & $0.36 \pm 0.26$ & $0.67 \pm 0.10^{*}$ & $3.01 \pm 0.16^{*}$ \\
\hline \multirow[t]{4}{*}{ Cell-cycle-related genes } & $f t s Z$ & $1.74 \pm 0.01^{*}$ & $1.09 \pm 0.48$ & $0.67 \pm 0.14$ & $2.66 \pm 0.09^{*}$ \\
\hline & parA & $1.43 \pm 0.03$ & $28.66 \pm 14.17^{*}$ & $1.76 \pm 0.09 *$ & $83.74 \pm 3.38^{*}$ \\
\hline & parB & $1.75 \pm 1.36$ & $1.07 \pm 0.56$ & $0.51 \pm 0.04^{*}$ & $1.87 \pm 0.15^{*}$ \\
\hline & $d n a A$ & $3.81 \pm 2.79$ & $3.98 \pm 1.41^{*}$ & $3.61 \pm 3.27$ & $0.71 \pm 0.53$ \\
\hline Bacteroid differentiation related gene & bacA & $1.63 \pm 1.35$ & $1.61 \pm 0.64$ & $3.41 \pm 0.27^{*}$ & $2.00 \pm 0.33^{*}$ \\
\hline
\end{tabular}

*T-test $P<0.05$.
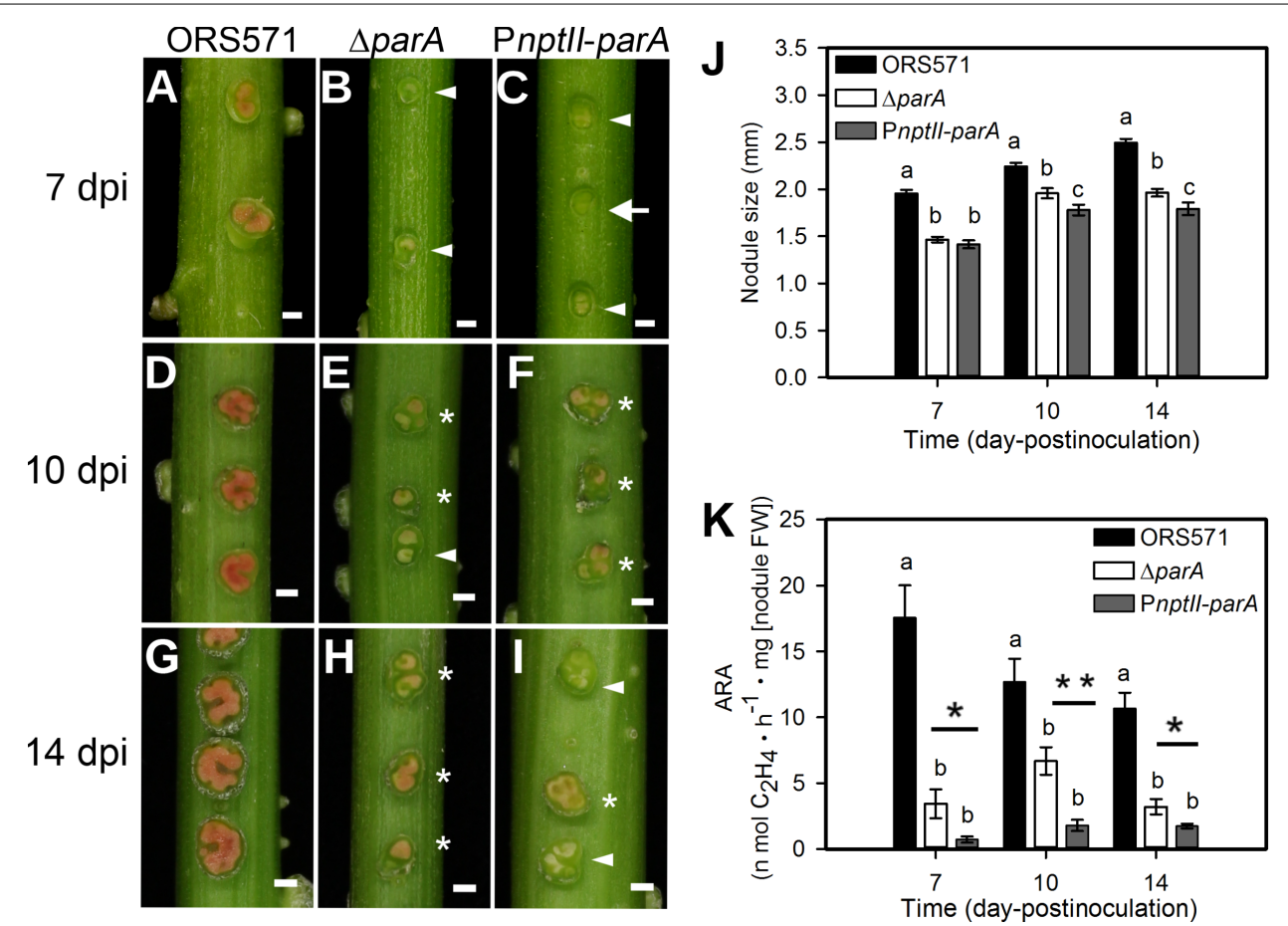

FIGURE 3 | Phenotypes of S. rostrata stem nodules induced by A. caulinodans and derivatives. (A-I) Stem nodules induced by ORS571 (A,D,G), $\triangle$ parA (B,E,H), and PnptII-parA (C,F,I). Arrowheads indicate beige stem nodules, asterisks mark pale red stem nodules, and arrows indicate green stem nodules. The scale bar represents $1 \mathrm{~mm}$. (J) The sizes of the stem nodules formed by ORS571 (black), $\Delta$ parA (white) and Pnptll-parA (gray) were calculated as the means of 30 nodules. The values are the means \pm standard deviations of five biological replicates. $P<0.05$ (post hoc analysis: Tukey). (K) Nitrogen-fixing activities of stem nodules. The stem nodules formed by each strain were harvested at 7, 10, and $14 \mathrm{dpi}$ and their nitrogenase activities were measured by the acetylene reducing assay (ARA). The values are the means \pm standard deviations of five biological replicates. $P<0.05$ (post hoc analysis: Tukey's HSD test). To distinguish the difference between the two mutants, a Student's $t$-test was further performed. ${ }^{*} P<0.05,{ }^{* *} P<0.05$. 
ORS571

A
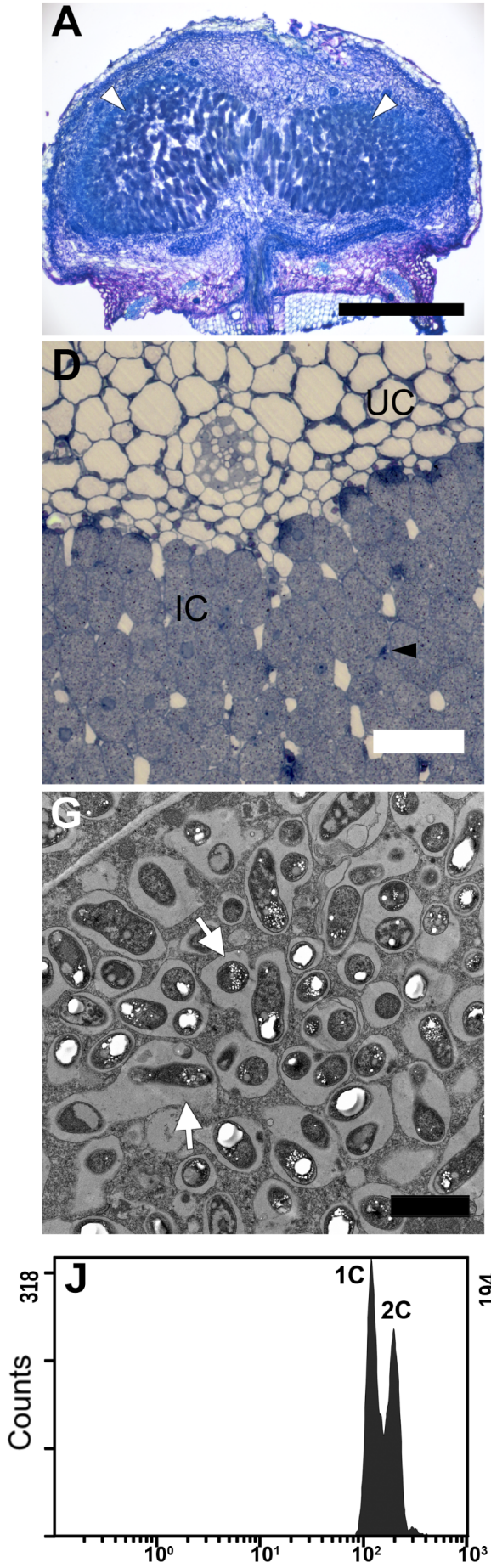

$\Delta$ parA
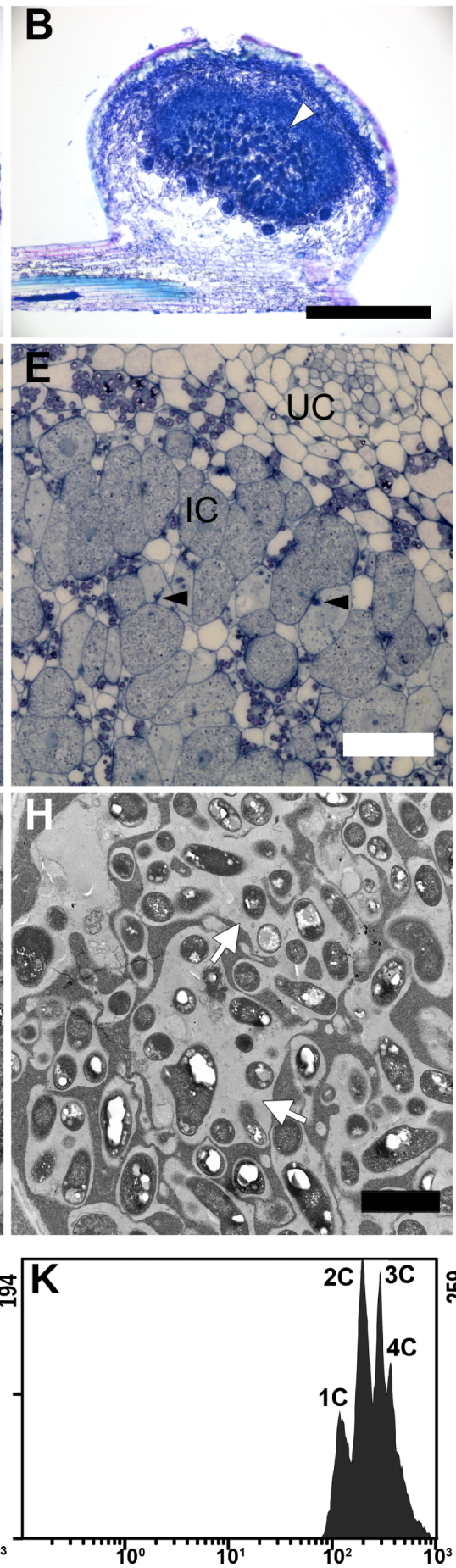

PnptII-parA

C
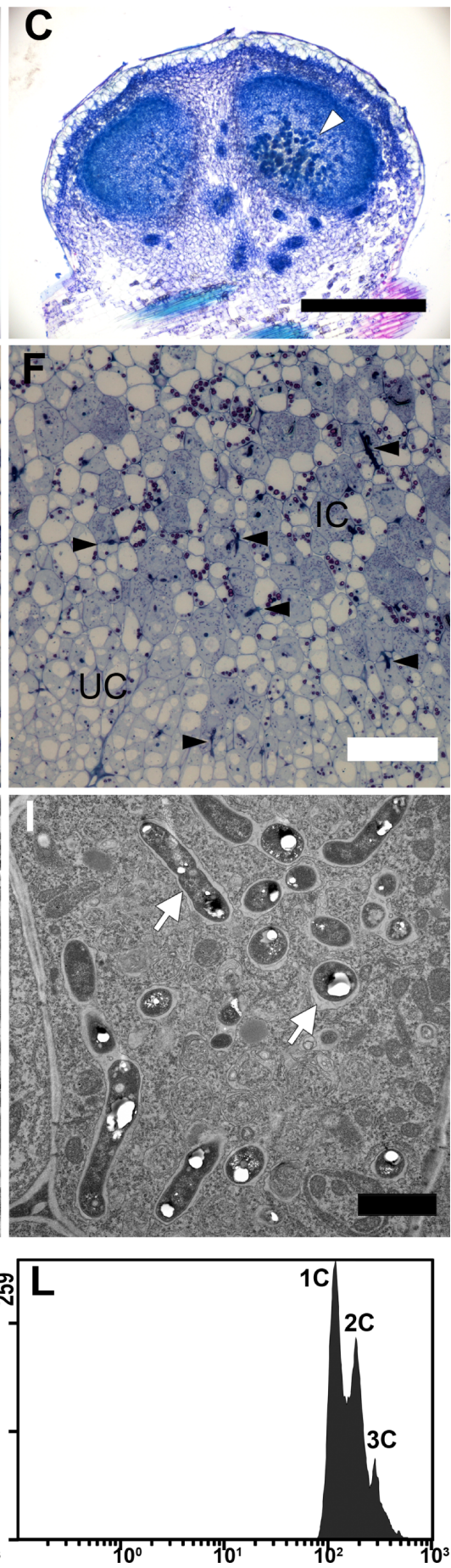

FIGURE 4 | Cytological characterization of 7-dpi stem nodules and their DNA contents in bacteroids. Stem nodules (7 dpi) formed by ORS571, $\Delta$ parA, and PnptI-parA. (A-C) Light micrographs of longitudinal sections stained with toluidine blue $\mathrm{O}$. White arrowheads indicate infection centers. (D-F) High magnification light micrographs. Black arrowheads indicate infection threads. (G-I) Transmission electron microscope (TEM) images. Arrows indicate peribacteroid membrane spaces. IC, infected cells; UC, uninfected cells. Scale bars represent $0.5 \mathrm{~mm}$ in panels (A-C), $50 \mu \mathrm{m}$ in panels (D-F), and $2 \mu \mathrm{m}$ in panels (G-I). (J-L) Bacteroids were isolated from $7 \mathrm{dpi}$ stem nodules and stained with propidium iodide (PI) for flow cytometry analyses. For each histogram, the $x$ axis shows fluorescence levels, which represent the DNA content per particle counted. The $y$ axis shows counts, which indicate the number of fluorescing particles or cells. In each experiment, 20,000 cells were analyzed. 
TABLE 4 | Gene expression in 5 dpi bacteroids.

\begin{tabular}{|c|c|c|c|}
\hline \multirow[b]{2}{*}{ Category } & \multirow[b]{2}{*}{ Gene name } & \multicolumn{2}{|c|}{ Gene expression } \\
\hline & & $\Delta p a r A / \mathrm{WT}$ & PnptII-parA/W1 \\
\hline \multirow[t]{5}{*}{ nod } & $\operatorname{nod} D$ & $0.93 \pm 0.03$ & $0.37 \pm 0.10^{*}$ \\
\hline & noeC & $5.28 \pm 0.10^{*}$ & $1.36 \pm 0.20$ \\
\hline & $\operatorname{nod} Z$ & $5.96 \pm 0.27^{*}$ & $1.59 \pm 0.23^{*}$ \\
\hline & $\operatorname{nod} B$ & $9.29 \pm 1.55^{*}$ & $5.67 \pm 0.88^{*}$ \\
\hline & nolk & $4.18 \pm 0.06^{*}$ & $0.53 \pm 0.01^{*}$ \\
\hline \multirow[t]{5}{*}{ nif/fix } & nifD & $2.68 \pm 0.18^{*}$ & $0.63 \pm 0.03^{*}$ \\
\hline & nifH2 & $1.39 \pm 0.01^{*}$ & $0.03 \pm 0.00^{*}$ \\
\hline & nifA & $1.09 \pm 0.07$ & $0.24 \pm 0.25^{*}$ \\
\hline & fixA & $0.26 \pm 0.01^{*}$ & $0.04 \pm 0.00^{*}$ \\
\hline & $f i x N$ & $0.59 \pm 0.06^{*}$ & $0.50 \pm 0.08^{*}$ \\
\hline \multirow[t]{4}{*}{ Polysaccharide } & oac3/expA7 & $7.57 \pm 5.22$ & $1.74 \pm 1.22$ \\
\hline & oac2/expA10 & $2.27 \pm 0.15^{*}$ & $1.28 \pm 0.04^{*}$ \\
\hline & oac1/expA9 & $1.67 \pm 0.36$ & $0.53 \pm 0.03^{*}$ \\
\hline & $\exp A 4$ & $6.64 \pm 0.32^{*}$ & $5.00 \pm 0.38^{*}$ \\
\hline \multirow[t]{4}{*}{ Cell-cycle-related genes } & ftsZ & $1.55 \pm 0.08^{*}$ & $1.73 \pm 0.03^{*}$ \\
\hline & parA & $2.05 \pm 0.25^{*}$ & $21.06 \pm 0.18^{*}$ \\
\hline & parB & $1.79 \pm 0.43^{*}$ & $0.68 \pm 0.07^{*}$ \\
\hline & $d n a A$ & $1.01 \pm 0.46$ & $3.18 \pm 0.12^{*}$ \\
\hline $\begin{array}{l}\text { Bacteroid differentiation } \\
\text { related gene }\end{array}$ & bacA & $1.58 \pm 0.04^{*}$ & $1.69 \pm 0.21^{*}$ \\
\hline
\end{tabular}

*T-test $P<0.05$.

the transcript levels of nodulation related genes (nod, noe and $n o l)$. In general, when the regulatory gene nodD is activated, it leads to the expression of the other nodulation related genes (Mergaert et al., 1996). We found that the nodD gene was downregulated in the PnptII-parA nodules; however, some other nodulation genes, such as $n o d \mathrm{~B}, n o d \mathrm{Z}$, and noeC, were upregulated. This result indicates that the expression of these genes was uncoupled from normal regulation. Moreover, this phenomenon could be corresponding to the finding shown in Supplementary Figure S2.

Based on the observed transcript levels, we deduced that the aberrant phenotype of the two parA mutant-induced nodulelike structures was due to a lack of coordination with the developmental stages of the host plant. We also noted that the transcripts of the symbiotic nitrogen-fixation genes nif and fix were repressed in the PnptII-parA stem nodules. However, only fix gene transcripts were reduced in the $\Delta$ parA stemnodules. These findings may explain the dramatic decrease in symbiotic nitrogen fixation activity in the plants elicited by the two parA mutants and the result that the decrease associated with PnptII-parA was more severe than that of $\triangle$ parA (Figure 3K). In rhizobia, surface polysaccharides (LPS, EPS, SPS, etc.) are also important for the establishment of effective symbiotic interactions with host legumes. We noticed that the expression levels of the EPS-production-related gene $(\operatorname{expA4)}$ in the $\triangle$ parA and PnptII-parA nodules were approximately 5- to 6-fold higher than those in the ORS571 nodules (Table 4). It has been proved that adequate amount of azorhizobial EPSs is indispensable for S. rostrata stem-nodule development (Gao et al., 2001; Mathis et al., 2005; Sato et al.,
2016). Accordingly, we deduced that the increased amount of EPSs is one of the factors resulted in aberrant phenotypes of the parA mutants. How the azorhizobial ParA protein involves in the regulation of exopolysaccharide production remains to be elucidated.

\section{RT-PCR Analyses of Plant Defense Response-Related Genes}

During the early stage of stem nodulation in $S$. rostrata, a Kunitz proteinase inhibitor ( $\mathrm{SrPI1}$ ) gene is expressed as a part of the plant defense mechanism (Lievens et al., 2004). As shown in Figure $\mathbf{5 A}$, the transcript levels of SrPI1 were upregulated and reached a maximum at the early stage of nodulation ( $3 \mathrm{dpi}$ ) and then decreased during nodule development, which is consistent with previous studies (Lievens et al., 2004). When the strains were inoculated on the stem of $S$. rostrata, the relative transcript levels of the SrPI1 gene in both the $\triangle$ parA and PnptII-parA nodules were higher than those of the wild type (Figure 5B) during nodule development (3-10 dpi), especially those of PnptII-parA.

Srprx1, which encodes a functional class III peroxidase isoform of $S$. rostrata, is also transiently expressed in the early stage of stem nodulation (Den Herder et al., 2007). Its expression is induced by compatible nodulation factors (NFs) and is affected by $\mathrm{H}_{2} \mathrm{O}_{2}$ produced in the bacterial infection pockets and infection threads during infection. As shown in Figure 5C, the transcript level of Srprx1 decreased during nodule development. However, the relative transcript levels of the Srprx1 gene induced by $\Delta$ parA or PnptII-parA were all dramatically higher than those elicited by the ORS571 during nodule development (3$10 \mathrm{dpi}$ ) (Figure 5D). This result suggests that the intracellular $\mathrm{H}_{2} \mathrm{O}_{2}$ concentrations during nodulation in $\Delta$ parA and PnptIIparA stem-nodules (3-10 dpi) are higher than those in the wild-type strain.

\section{DISCUSSION}

Chromosomal Par proteins have been studied in many bacteria, and their absence or overproduction causes defects in segregation or/and cellular processes that include chromosome replication and cell division (Draper and Gober, 2002; Schofield et al., 2010). In our previous study, we found that a parA gene (AZC_4711) in-frame deletion mutant of A. caulinodans ORS571 ( $\triangle$ parA) showed a pleiomorphic cell shape phenotype and was polyploid, with differences in nucleoid sizes (Liu et al., 2011). In this study, overexpression of the parA gene in ORS571 resulted in minor effects in the free-living state (Figure 2). On the other hand, it caused severe aberrant symbiotic phenotypes, indicating this mutation exerts specific effects on symbiosis.

As shown in Figure 2, the viability, morphology and DNA content of this bacterium (PnptII-parA) were indistinguishable from those of ORS571 cells. The PnptII-parA strain harbored a plasmid that expressed the parA gene constitutively under the control of the nptII promoter, and the ParA protein level in this bacterium was indeed significantly elevated in comparison 

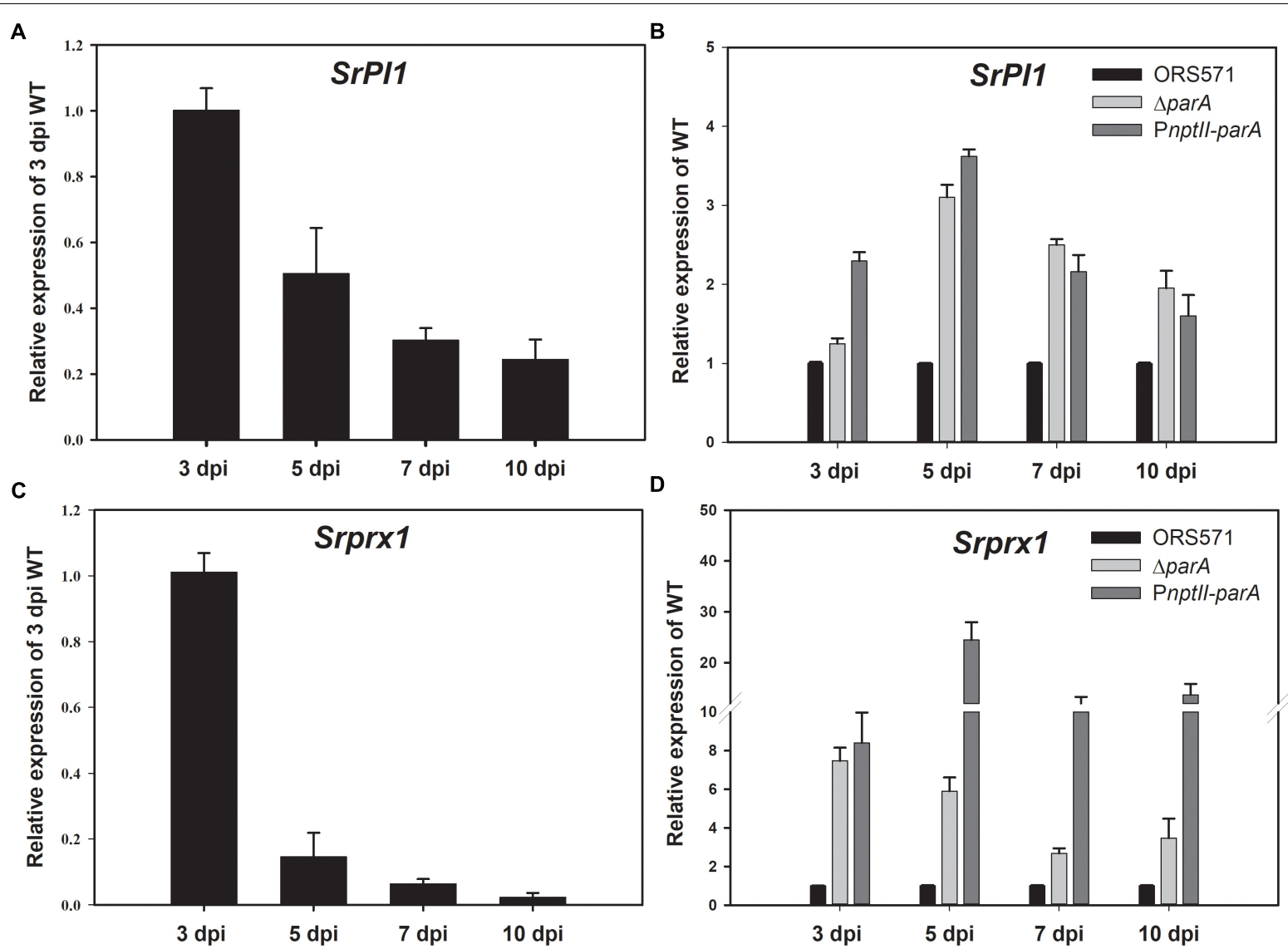

FIGURE 5 | Plant defense response-related genes. Expression of the plant immune response-related genes SrP/1 and Srprx1 during nodulation. SrPI1 expression pattern in ORS571-inoculated plants is shown as relative mRNA expression compared to 3 dpi ORS571 (A), and SrPI1 expression in $\triangle$ parA and PnptII-parA is shown as relative expression compared to ORS571 at the same time point (B). (C) Srprx1 expression profile of ORS571 shown as relative mRNA expression compared to 3 dpi ORS571. (D) $\Delta$ parA and PnptI-parA Srprx1 gene expression shown as relative mRNA expression compared to ORS571 at the same time point. The values are the means \pm standard deviations of three biological replicates.

with that of the wild-type strain (ORS571) (Figure 1). It has been considered that bacterial chromosome partitioning and cell division are tightly connected cellular processes. To maintain bacterial shape, cytoskeletal element genes, such as fts $Z$ and $m r e B$, should be tightly regulated during cell division (Cabeen and Jacobs-Wagner, 2005). Generally, overproduction of chromosome partitioning proteins in most bacteria leads to changes in morphology and the cell cycle, with varying severity. For example, increasing ParA proteins in C. crescentus resulted in elongated cells and cell division defects (Mohl and Gober, 1997). In P. aeruginosa, overexpressing the native parA gene at different levels led to morphological changes (filamentous or enlarged cells) and strong growth defects (Lasocki et al., 2007). In addition, the population of anucleate cells was increased, and the cell motility was dramatically affected (Lasocki et al., 2007). In B. subtilis, overproduction of the ParA ortholog (Soj) caused aberrant replication initiation, resulting in elongated cells harboring expanded nucleoids (Ogura et al., 2003). However, overexpression of a ParA ortholog (SegA) in an archaeon, Sulfolobus solfataricus, did not affect the normal growth rate, although severe chromosome segregation defects occurred (Kalliomaa-Sanford et al., 2012). Genetic robustness or genetic compensation is a phenomenon conserved in numerous prokaryotes and eukaryotes, which require buffering systems to ensure similar developmental outcomes despite minor differences in genetic makeup or environmental conditions (El-Brolosy and Stainier, 2017). The loss or overexpression of related gene(s), especially for those involved in tightly regulated cellular networks, may be compensated by others with overlapping functions (i.e., functionally redundant genetic pathways) and expression patterns (i.e., transcriptional modulation/transcriptional adaptation) to overcome stochastic fluctuations in gene and protein expression (Tautz, 1992; ElBrolosy et al., 2018). Accordingly, we deduced that one or more paralogous genes or underlying mechanisms provide functional physiological redundancy to maintain the morphology of PnptII-parA cells.

Notably, when PnptII-parA was cultivated in minimal broth (L2-N) under microaerobic condition (i.e., nitrogenfixing state), this strain revealed a very high expression level of the parA gene (Table 3). In general, the expression levels of nodulation genes in vegetative azorhizobial cells 
are induced only when a flavonoid (naringenin) is added to the culture medium (Tsukada et al., 2009). However, we noticed the expression levels of some symbiosis-related genes, including nodulation genes, nitrogen-fixation genes, and surface polysaccharide-related genes, were drastically induced in the nitrogen-fixing state without flavonoid addition (Table 3 ). In contrast, when PnptII-parA was cultivated with naringenin, only nodD gene was enhanced, those of the other target nodulation genes were declined (Supplementary Figure S2). It suggests that the nodulation genes in the PnptII-parA mutant were not mediated normally by the plant flavonoid. This phenomenon was reminiscent of the spontaneous flavonoid independent transcription activation (FITA) mutants of nodD in Sinorhizobium meliloti (Spaink et al., 1989) and in S. fredii (Vinardell et al., 2004). Legume roots secrete flavonoids, which are specifically recognized by NodD and bind to nod boxes and activate the transcription of nod genes (Maj et al., 2010). Expression of nod genes results in the production and secretion of Nod factors (lipochitooligosaccharides) and then initiate the nodulation program. A. caulinodans ORS571 nod genes are known to be induced by specific $S$. rostrata flavonoids (Goethals et al., 1990). Taken together, we deduced that the PnptII-parA cells initiated symbiosis in S. rostrata via a still-unidentified flavonoid-independent pathway, causing a nodule-like structure and impaired symbiotic nitrogen fixation (Figure 3). Further work to elucidate the underlying mechanism of this phenomenon, such as constructing a gain-of-function mutant (i.e., $\Delta$ nodD harbored with PnptII-parA plasmid) to conduct genetic and physiological analyses remains to be done.

After rhizobia are released from the infection threads (ITs), they reside in the host cytoplasm as organelle-like structures, called symbiosomes. They comprise the bacteroids, the peribacteroid membrane (symbiosome membrane) and the space between them (Defaria et al., 1986). As shown in Figure 4I, we observed that individual bacterium was closely surrounded by the peribacteroid membrane in one symbiosome, distributed in the cytoplasm of PnptII-parA nodules. The nitrogen-fixing ability $\left(\mathrm{C}_{2} \mathrm{H}_{2}\right.$-reduction) of the stem-nodules was confirmed by ARA measurement, however, the values were greatly reduced compared with the wild type (Figure $3 \mathbf{K}$ ). It was also consistent with the transcription of nitrogen fixation genes (nif and $f(x)$ in the PnptII-parA stem nodules (Table 4). According to microscopy, there were several enlarged ITs and only a few internalized bacteria observed in the cortical cells (Figure 4 and Supplementary Figure S3). It has been known that rhizobia don't fix nitrogen within ITs until they differentiate into bacteroids in symbiosomes. Taken together, we deduced that a majority of PnptII-parA was retained within the ITs in the analyzed nodules, and only a small portion of this bacterium could successfully release from the ITs and differentiate into nitrogenfixing bacteroids.

As shown in Figure 4G, one or multiple ORS571 bacteroids with a broad symbiosome space were enclosed within the symbiosome compartment in the 7 dpi-old-stem-nodules. These wild type bacteroids were mainly haploid and diploid (1C and $2 \mathrm{C}$ ) (Figure 4J). In the fully mature stage (14 dpi), they would become polyploid $(2 \mathrm{C}, 3 \mathrm{C}$, and $4 \mathrm{C})$, but the space between the symbiosome membrane and bacteroids were still large (Liu et al., 2011). In contrast, the PnptII-parA symbiosome had a remarkable trait, in which each single pleomorphic-shaped bacteroid was closely surrounded by a peribacteroid membrane in the PnptII-parA stem-nodules (7 dpi) (Figure 4I). Besides, elevated DNA content was already observed in the PnptII-parA bacteroids, although it was not as marked as that in the $\triangle$ parA bacteroids (Figure 4L). We noticed these distinctive features of PnptII-parA bacteroid (i.e., single swollen bacteroid, relatively narrow symbiosome space, and multinucleoid [polyploid] cells, etc.) are reminiscent of the terminally differentiated bacteroids in some IRLC indeterminate nodules (Mergaert et al., 2006; Jones et al., 2007; Oono et al., 2010). To the best of our knowledge, there have been no previous reports of such bacteroid morphotypes within the root or stem nodules of $S$. rostrata.

Many studies have shown that bacteroid differentiation fates (terminal differentiation) are mediated by plant factors that show similarities to defensin-like innate immunity factors and have been designated as NCR peptides; these factors are present in the nodules of IRLC and Dalbergoid (Aeschynomene spp.) clade legumes (Van De Velde et al., 2010; Czernic et al., 2015). S. rostrata has been classified as a member of the Robinioid clade in the Papilionoideae (Sprent, 2007), implying that its nodules do not produce NCR peptides. The mature stem-nodules of S. rostrata are regarded as determinate (Goormachtig et al., 1997), meaning that the endosymbionts will divide after a time within the plant membrane and form one or multiple bacteroids with a broad symbiosome space via peribacteroid membrane fusion or further bacterial division (Brewin, 2004). Such symbiosomes are also observed in Lotus japonicus, soybean (Glycine max), bean (Phaseolus vulgaris), etc (Kereszt et al., 2011). Van de Velde and colleagues reported that expression of heterologous NCR genes (derived from IRLC legume) in L. japonicus would also generate polyploid and enlarged Mesorhizobium loti bacteroids with a narrow symbiosome space within the majority of symbiotic cells (Van De Velde et al., 2010). Terminal bacteroid differentiation is a cell-cycle-related process, and the formation of the single swollen bacteroids present in symbiosomes is known to be mediated by NCR peptides that affect the bacterial cell cycle, provoke membrane modifications, inhibit bacterial cytokinesis, and promote DNA amplification coupled with cell enlargement (Mergaert, 2018). In many bacteria, deletion or overproduction of the chromosomal par genes results in some defects in segregation and/or cellular processes (Draper and Gober, 2002; Schofield et al., 2010). As shown in Table 4, the relative transcript level of the DNA replication-related gene $d n a A$ was significantly upregulated in the PnptII-parA bacteroids, and this phenomenon may be related to their polyploidy (Figure $4 \mathrm{~L}$ ). Because $S$. rostrata is not supposed to produce NCR peptides, we propose that the formation of this symbiosome type in the PnptII-parA stemnodules is due to the severe cell cycle disturbance elicited by the excess of ParA proteins in the symbiotic cells during nodulation.

As shown in Supplementary Figure S3, several abnormally proliferated infection threads were formed in the central cortical tissues of the PnptII-parA stem-nodules. A gibberellin (GA) biosynthesis related gene, SrGA20ox1, was known to be involved in infection thread formation in $S$. rostrate 
(Lievens et al., 2005). Its transcript was up-regulated during early nodulation of stem-nodule. Accordingly, we conducted RT-PCR

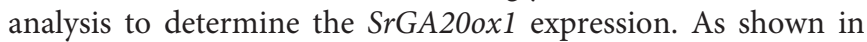
Supplementary Figure S4A, the transcript levels of ORS571 infected nodule were upregulated and reached a maximum at the early stage of nodulation ( $3 \mathrm{dpi}$ ) and then decreased during nodule development, and almost disappeared in the $7 \mathrm{dpi}$ stemnodule. It indicates that the formation of infection threads was active at early stage, and stopped in subsequent stages of nodule development. On the other hand, the relative transcripts of PnptII-parA infected nodule kept at relatively high levels during nodule development (3-7 dpi) (Supplementary Figure S4B). It suggests that the huge number of large infection threads in the PnptII-parA nodule was due to persistent induction of infection threads expansion and invagination. In general, signs of defense could be associated with an attempt by the plant to limit bacterial multiplication. The enlarged infection threads also suggest the induction of a plant defense response accompanied with massive $\mathrm{H}_{2} \mathrm{O}_{2}$ accumulation (D'haeze et al., 2004). As shown in Figure 5, the relative transcript levels of the plant defense response-related genes (SrPI1 and Srprx1) induced by PnptII-parA were dramatically higher than those elicited by the ORS571 during nodule development (3-10 dpi). It suggests that the stem-nodules induced by PnptII-parA mutant exhibited higher levels of oxidative stress than those induced by wild type.

In a preliminary experiment, we found that the EPS production of the ORS571 derivatives was remarkably increased at high concentration of $\mathrm{H}_{2} \mathrm{O}_{2}(5 \mathrm{mM})$ (upper panel of Supplementary Figure S5). We noticed that the viability of individual strains under the same dosage of hydrogen peroxide treatment was approximately the same (middle panel of Supplementary Figure S5). We further determined the outer membrane permeabilities of the ORS571 derivatives by propidium iodide (PI) staining. As shown in bottom panel of Supplementary Figure S5, we found the cell permeability of the PnptII-parA mutant was dramatically higher than that of either wild type or $\triangle$ parA mutant whether it is treated with $\mathrm{H}_{2} \mathrm{O}_{2}$ or not. In general, the increased membrane penetrability is the direct evidence of cell membrane damage in the response to stress. It indicates that PnptII-parA cells are supposed to be more easily damaged by the environmental stress than the other two strains. Unexpectedly, the tolerance of PnptIIparA toward $\mathrm{H}_{2} \mathrm{O}_{2}$ was comparable with ORS571 (middle panel of Supplementary Figure S5). It has been proposed that massive $\mathrm{H}_{2} \mathrm{O}_{2}$ accumulation was induced by PnptII-parA mutant during nodulation, while the expression level of the EPSproduction-related gene (expA4) of the PnptII-parA bacteroids was significantly higher ( $\sim 5$ folds) than that of the ORS571 bacteroids (Table 4). Since EPS synthesized by bacteria are thought to be adaptations to environmental stresses (Lloret et al., 1998), it is likely that PnptII-parA cells may mitigate the oxidative stress by elevated levels of EPS production during nodulation.

Some features of PnptII-parA nodule phenotype were reminiscent of ORS571-oac2 mutant induced stem-nodule (Gao et al., 2001; Mathis et al., 2005). Strain ORS571-oac2 has truncated LPS, and produces less EPS in comparison with that of wild type. The development of ORS571-oac2 induced stemnodule was arrested at early stage. There were several enlarged, thick-walled infection threads formed, which was due to the infection steps continuously repeated in the nodule. Notably, there were also some features different from those of PnptIIparA stem-nodules. For example, bacterial exit from infection threads was completely blocked in the ORS571-oac2 stemnodule (Mathis et al., 2005), whereas bacterial internalization and bacteroid formation was observed in the central cortical tissue of PnptII-parA stem-nodules (Figure 4). Besides, no nitrogenfixing activity was detected in the former (Gao et al., 2001), in contrast, nitrogenase enzyme activity (ARA) was detected in the latter although it was dramatically reduced (Figure 3K).

\section{CONCLUSION}

Based on the phenotypic and gene expression analysis data in this study, we deduced that the particular symbiotic phenotype induced by PnptII-parA mutant is due to a lack of coordination with the developmental stages of the host plant. It results in polymorphic infection and organogenesis patterns, such as earlier occurring problem during the infection process and/or release from ITs as well as altered bacteroid differentiation. Since both the deletion and overexpression of the A. caulinodans parA gene result in aberrant symbiotic phenotypes and remarkably reduced performance, indicating ParA protein homeostasis should be tightly regulated in A. caulinodans at the correct level.

\section{PERSPECTIVES}

It has been widely accepted that bacteroid morphology (swollen or non-swollen) is controlled by legume host factors rather than rhizobial genotype (Oono et al., 2010). In this study, we characterized different bacteroid formation traits (swollen and non-swollen) that were induced by two azorhizobial strains with the same genotype (ORS571 and PnptII-parA) in the same legume host (S. rostrata). This symbiotic system could serve as an excellent model for investigating the molecular mechanisms by which host legumes recognize and discriminate among effective and ineffective rhizobial strains. Furthermore, we could also explore the adaptation mechanisms of the same rhizobial strain within different types of symbiosomes, which will help to identify additional determinants of the interactions between host cells and bacteroids.

\section{DATA AVAILABILITY STATEMENT}

The datasets generated for this study are available on request to the corresponding author.

\section{AUTHOR CONTRIBUTIONS}

H-LC carried out most of the experiments, experimental data analysis, and manuscript writing. $\mathrm{W}-\mathrm{ZH}$ and $\mathrm{M}-\mathrm{YT}$ constructed 
the parA overexpression mutant. $\mathrm{W}-\mathrm{ZH}$ analyzed the ParA protein expression level. C-HC provided technical assistance with TEM. C-TL is the corresponding authors in charge of the project design, and manuscript writing.

\section{FUNDING}

This study was supported by grants from the Ministry of Science and Technology (MOST 107-2313-B-002024 and 107-2321-B-001-033) and Industrial Technology Research Institute.

\section{REFERENCES}

Akiba, N., Aono, T., Toyazaki, H., Sato, S., and Oyaizu, H. (2010). phrR-like gene praR of Azorhizobium caulinodans ORS571 is essential for symbiosis with Sesbania rostrata and is involved in expression of reb genes. Appl. Environ. Microbiol. 76, 3475-3485. doi: 10.1128/AEM.00238-10

Bartosik, A. A., Glabski, K., Jecz, P., Lasocki, K., Mikosa, M., Plochocka, D., et al. (2014). Dissection of the region of Pseudomonas aeruginosa ParA that is important for dimerization and interactions with its partner ParB. Microbiology 160, 2406-2420. doi: 10.1099/mic.0.081216-0

Bartosik, A. A., Mierzejewska, J., Thomas, C. M., and Jagura-Burdzy, G. (2009). ParB deficiency in Pseudomonas aeruginosa destabilizes the partner protein ParA and affects a variety of physiological parameters. Microbiology 155, 10801092. doi: $10.1099 / \mathrm{mic} .0 .024661-0$

Beringer, J. E. (1974). R-factor transfer in Rhizobium leguminosarum. J. Gen. Microbiol. 84, 188-198. doi: 10.1099/00221287-84-1-188

Bignell, C., and Thomas, C. M. (2001). The bacterial ParA-ParB partitioning proteins. J. Biotechnol. 91, 1-34. doi: 10.1016/s0168-1656(01)00293-0

Brewin, N. (2004). Plant cell wall remodelling in the Rhizobium-legume symbiosis. J. Crit. Rev. Plant Sci. 23, 293-316. doi: 10.1080/07352680490480734

Cabeen, M. T., and Jacobs-Wagner, C. (2005). Bacterial cell shape. Nat. Rev. Microbiol. 3, 601-610.

Corich, V., Goormachtig, S., Lievens, S., Van Montagu, M., and Holsters, M. (1998). Patterns of ENOD40 gene expression in stem-borne nodules of Sesbania rostrata. Plant Mol. Biol. 37, 67-76.

Czernic, P., Gully, D., Cartieaux, F., Moulin, L., Guefrachi, I., Patrel, D., et al. (2015). Convergent evolution of endosymbiont differentiation in dalbergioid and inverted repeat-lacking clade legumes mediated by nodule-specific cysteine-rich peptides. Plant Physiol. 169, 1254-1265. doi: 10.1104/pp.15.00584

Defaria, S. M., Sutherland, J. M., and Sprent, J. I. (1986). A new type of infected cell in root-nodules of Andira spp (Leguminosae). Plant Sci. 45, 143-147. doi: 10.1016/0168-9452(86)90050-6

Den Herder, J., Lievens, S., Rombauts, S., Holsters, M., and Goormachtig, S. (2007). A symbiotic plant peroxidase involved in bacterial invasion of the tropical legume Sesbania rostrata. Plant Physiol. 144, 717-727. doi: 10.1104/pp.107. 098764

D’haeze, W., Glushka, J., De Rycke, R., Holsters, M., and Carlson, R. W. (2004). Structural characterization of extracellular polysaccharides of Azorhizobium caulinodans and importance for nodule initiation on Sesbania rostrata. Mol. Microbiol. 52, 485-500. doi: 10.1111/j.1365-2958.2004.03989.x

Dilworth, M. J. (1966). Acetylene reduction by nitrogen-fixing preparations from Clostridium pasteurianum. Biochim. Biophys. Acta 127, 285-294. doi: 10.1016/ 0304-4165(66)90383-7

Dombrecht, B., Vanderleyden, J., and Michiels, J. (2001). Stable RK2-derived cloning vectors for the analysis of gene expression and gene function in Gramnegative bacteria. Mol. Plant Microbe Interact. 14, 426-430. doi: 10.1094/mpmi. 2001.14.3.426

Donald, R. G. K., Nees, D., Raymond, C. K., Loroch, A. I., and Ludwig, R. A. (1986). Three genomic loci encode Rhizobium sp. ORS571 N2 fixation genes. J. Bacteriol. 165, 72-81. doi: 10.1128/jb.165.1.72-81.1986

Downie, J. A. (2014). Legume nodulation. Curr. Biol. 24, R184-R190.

\section{ACKNOWLEDGMENTS}

We thank the Joint Center for Instruments and Researchers, College of Bio-Resources and Agriculture, NTU, for their technical assistance with flow cytometry analyses and TEM.

\section{SUPPLEMENTARY MATERIAL}

The Supplementary Material for this article can be found online at: https://www.frontiersin.org/articles/10.3389/fmicb. 2019.02422/full\#supplementary-material

Draper, G. C., and Gober, J. W. (2002). Bacterial chromosome segregation. Ann. Rev. Microbiol. 56, 567-597.

Dreyfus, B., Garcia, J. L., and Gillis, M. (1988). Characterization of Azorhizobium caulinodans gen. nov., sp. nov., a stemnodulating nitrogen-fixing bacterium isolated from Sesbania rostrata. Int. J. Syst. Bacteriol. 38, 89-98. doi: 10.1099/ 00207713-38-1-89

Dreyfus, B. L., Elmerich, C., and Dommergues, Y. R. (1983). Free-living Rhizobium strain able to grow on N2 as the sole nitrogen source. Appl. Environ. Microbiol. $45,711-713$.

Easter, J. Jr., and Gober, J. W. (2002). ParB-stimulated nucleotide exchange regulates a switch in functionally distinct ParA activities. Mol. Cell 10, 427-434. doi: 10.1016/s1097-2765(02)00594-4

El-Brolosy, M., Rossi, A., Kontarakis, Z., Kuenne, C., Guenther, S., Fukuda, N., et al. (2018). Genetic compensation is triggered by mutant mRNA degradation. bioRxiv [Preprint] 328153. doi: 10.1101/328153

El-Brolosy, M. A., and Stainier, D. Y. R. (2017). Genetic compensation: a phenomenon in search of mechanisms. PLoS Genet. 13:e1006780. doi: 10.1371/ journal.pgen.1006780

Gao, M. S., D’haeze, W., De Rycke, R., Wolucka, B., and Holsters, M. (2001). Knockout of an azorhizobial dTDP-L-rhamnose synthase affects lipopolysaccharide and extracellular polysaccharide production and disables symbiosis with Sesbania rostrata. Mol. Plant Microbe Interact. 14, 857-866. doi: 10.1094/mpmi.2001.14.7.857

Gibson, K. E., Kobayashi, H., and Walker, G. C. (2008). Molecular determinants of a symbiotic chronic infection. Ann. Rev. Genet. 42, 413-441. doi: 10.1146/ annurev.genet.42.110807.091427

Goethals, K., Vandeneede, G., Vanmontagu, M., and Holsters, M. (1990). Identification and characterization of a functional nodd gene in azorhizobiumcaulinodans Ors571. J. Bacteriol. 172, 2658-2666. doi: 10.1128/jb.172.5.26582666.1990

Goormachtig, S., Alves-Ferreira, M., Van Montagu, M., Engler, G., and Holsters, M. (1997). Expression of cell cycle genes during Sesbania rostrata stem nodule development. Mol. Plant Microbe Interact. 10, 316-325.

Gordon, G. S., Sitnikov, D., Webb, C. D., Teleman, A., Straight, A., Losick, R., et al. (1997). Chromosome and low copy plasmid segregation in E. coli: visual evidence for distinct mechanisms. Cell 90, 1113-1121. doi: 10.1016/s00928674(00)80377-3

Gordon, G. S., and Wright, A. (2000). DNA segregation in bacteria. Ann. Rev. Microbiol. 54, 681-708. doi: 10.1146/annurev.micro.54.1.681

Hiraga, S. (1993). Chromosome partition in Echerichia coli. Curr. Opin. Genet. Dev. 5, 789-801. doi: 10.1016/s0959-437x(05)80100-5

Hiraga, S. (2000). Dynamic localization of bacterial and plasmid chromosomes. Ann. Rev. Genet. 34, 21-59. doi: 10.1146/annurev.genet.34.1.21

Hirsch, A. M. (1992). Developmental biology of legume nodulation. New Phytol. 122, 211-237. doi: 10.1111/j.1469-8137.1992.tb04227.x

Iniesta, A. A. (2014). ParABS system in chromosome partitioning in the bacterium Myxococcus xanthus. PLoS One 9:e86897. doi: 10.1371/journal.pone.0086897

Ireton, K., Gunther, N. W. T., and Grossman, A. D. (1994). spo0J is required for normal chromosome segregation as well as the initiation of sporulation in Bacillus subtilis. J. Bacteriol. 176, 5320-5329. doi: 10.1128/jb.176.17.5320-5329. 1994 
Jones, K. M., Kobayashi, H., Davies, B. W., Taga, M. E., and Walker, G. C. (2007). How rhizobial symbionts invade plants: the Sinorhizobium-Medicago model. Nat. Rev. Microbiol. 5, 619-633. doi: 10.1038/nrmicro1705

Kalliomaa-Sanford, A. K., Rodriguez-Castaneda, F. A., Mcleod, B. N., LatorreRosello, V., Smith, J. H., Reimann, J., et al. (2012). Chromosome segregation in Archaea mediated by a hybrid DNA partition machine. Proc. Natl. Acad. Sci. U.S.A. 109, 3754-3759. doi: 10.1073/pnas.1113384109

Kereszt, A., Mergaert, P., and Kondorosi, E. (2011). Bacteroid development in legume nodules: evolution of mutual benefit or of sacrificial victims? Mol. Plant Microbe Interact. 24, 1300-1309. doi: 10.1094/mpmi-06-11-0152

Kusiak, M., Gapczynska, A., Plochocka, D., Thomas, C. M., and Jagura-Burdzy, G. (2011). Binding and spreading of ParB on DNA determine its biological function in Pseudomonas aeruginosa. J. Bacteriol. 193, 3342-3355. doi: 10.1128/ JB.00328- 11

Lasocki, K., Bartosik, A. A., Mierzejewska, J., Thomas, C. M., and Jagura-Burdzy, G. (2007). Deletion of the parA (soj) homologue in Pseudomonas aeruginosa causes ParB instability and affects growth rate, chromosome segregation, and motility. J. Bacteriol. 189, 5762-5772. doi: 10.1128/jb.00371-07

Lee, P. S., and Grossman, A. D. (2006). The chromosome partitioning proteins Soj (ParA) and Spo0J (ParB) contribute to accurate chromosome partitioning, separation of replicated sister origins, and regulation of replication initiation in Bacillus subtilis. Mol. Microbiol. 60, 853-869. doi: 10.1111/j.1365-2958.2006. 05140.x

Lievens, S., Goormachtig, S., Den Herder, J., Capoen, W., Mathis, R., Hedden, P., et al. (2005). Gibberellins are involved in nodulation of Sesbania rostrata. Plant Physiol. 139, 1366-1379. doi: 10.1104/pp.105.066944

Lievens, S., Goormachtig, S., and Holsters, M. (2004). Nodule-enhanced protease inhibitor gene: emerging patterns of gene expression in nodule development on Sesbania rostrata. J. Exp. Bot. 55, 89-97. doi: 10.1093/jxb/erh015

Liu, C. T., Lee, K. B., Wang, Y. S., Peng, M. H., Lee, K. T., Suzuki, S., et al. (2011). Involvement of the azorhizobial chromosome partition gene (parA) in the onset of bacteroid differentiation during Sesbania rostrata stem nodule development. Appl. Environ. Microbiol. 77, 4371-4382. doi: 10.1128/AEM.02327-10

Lloret, J., Wulff, B. B. H., Rubio, J. M., Downie, J. A., Bonilla, I., and Rivilla, R. (1998). Exopolysaccharide II production is regulated by salt in the halotolerant strain Rhizobium meliloti EFB1. Appl. Environ. Microbiol. 64, 1024-1028.

Maj, D., Wielbo, J., Marek-Kozaczuk, M., and Skorupska, A. (2010). Response to flavonoids as a factor influencing competitiveness and symbiotic activity of Rhizobium leguminosarum. Microbiol. Res. 165, 50-60. doi: 10.1016/j.micres. 2008.06.002

Mathis, R., Van Gijsegem, F., De Rycke, R., D’haeze, W., Van Maelsaeke, E., Anthonio, E., et al. (2005). Lipopolysaccharides as a communication signal for progression of legume endosymbiosis. Proc. Natl. Acad. Sci. U.S.A. 102, 2655-2660. doi: 10.1073/pnas.04098 16102

Mergaert, P. (2018). Role of antimicrobial peptides in controlling symbiotic bacterial populations. Nat. Prod. Rep. 35, 336-356. doi: 10.1039/c7np0 $0056 \mathrm{a}$

Mergaert, P., Dhaeze, W., Fernandezlopez, M., Geelen, D., Goethals, K., Claudeprome, J., et al. (1996). Fucosylation and arabinosylation of Nod factors in Azorhizobium caulinodans: involvement of nolK, nodZ as well as noeC and/or downstream genes. Mol. Microbiol. 21, 409-419. doi: 10.1046/j.13652958.1996.6451366.x

Mergaert, P., Uchiumi, T., Alunni, B., Evanno, G., Cheron, A., Catrice, O., et al. (2006). Eukaryotic control on bacterial cell cycle and differentiation in the Rhizobium-legume symbiosis. Proc. Natl. Acad. Sci. U.S.A. 103, 5230-5235. doi: 10.1073/pnas.0600912103

Mierzejewska, J., and Jagura-Burdzy, G. (2012). Prokaryotic ParA-ParB-parS system links bacterial chromosome segregation with the cell cycle. Plasmid 67, 1-14. doi: 10.1016/j.plasmid.2011.08.003

Mohl, D. A., Easter, J. Jr., and Gober, J. W. (2001). The chromosome partitioning protein, ParB, is required for cytokinesis in Caulobacter crescentus. Mol. Microbiol. 42, 741-755. doi: 10.1046/j.1365-2958.2001.02643.x

Mohl, D. A., and Gober, J. W. (1997). Cell cycle-dependent polar localization of chromosome partitioning proteins in Caulobacter crescentus. Cell 88, 675-684. doi: 10.1016/s0092-8674(00)81910-8

Montiel, J., Szucs, A., Boboescu, I. Z., Gherman, V. D., Kondorosi, E., and Kereszt, A. (2016). Terminal bacteroid differentiation is associated with variable morphological changes in legume species belonging to the inverted repeatlacking clade. Mol. Plant Microbe Interact. 29, 210-219. doi: 10.1094/MPMI09-15-0213-R

Murray, H., and Errington, J. (2008). Dynamic control of the DNA replication initiation protein DnaA by Soj/ParA. Cell 135, 74-84. doi: 10.1016/j.cell.2008. 07.044

Ndoye, I., De Billy, F., Vasse, J., Dreyfus, B., and Truchet, G. (1994). Root nodulation of Sesbania rostrata. J. Bacteriol. 176, 1060-1068. doi: 10.1128/jb. 176.4.1060-1068.1994

O'brien, T. P., Feder, N., and Mccully, M. E. (1964). Polychromatic staining of plant cell walls by toluidine blue O. Protoplasma 59, 367-373.

Ogura, Y., Ogasawara, N., Harry, E. J., and Moriya, S. (2003). Increasing the ratio of Soj to Spo0J promotes replication initiation in Bacillus subtilis. J. Bacteriol. 185, 6316-6324. doi: 10.1128/jb.185.21.6316-6324.2003

Oono, R., and Denison, R. F. (2010). Comparing symbiotic efficiency between swollen versus nonswollen rhizobial bacteroids. Plant Physiol. 154, 1541-1548. doi: 10.1104/pp.110.163436

Oono, R., Schmitt, I., Sprent, J. I., and Denison, R. F. (2010). Multiple evolutionary origins of legume traits leading to extreme rhizobial differentiation. New Phytol. 187, 508-520. doi: 10.1111/j.1469-8137.2010.03261.x

Rowe, D. C. D., and Summers, D. K. (1999). The quiescent-cell expression system for protein synthesis in Escherichia coli. Applied and Environmental Microbiology 65, 2710-2715.

Sato, S., Siarot, L., Matsuoka, J.-I., Aono, T., and Oyaizu, H. (2016). An Azorhizobium caulinodans ORS571 mutant with deletion of a gene encoding a TIGR02302 family protein overproduces exopolysaccharides and is defective in infection into plant host cells. Soil Sci. Plant Nutr. 62, 392-398. doi: 10.1080/ 00380768.2016.1200954

Schneider, C. A., Rasband, W. S., and Eliceiri, K. W. (2012). NIH image to ImageJ: 25 years of image analysis. Nat. Methods 9, 671-675. doi: 10.1038/nmeth.2089

Schofield, W. B., Lim, H. C., and Jacobs-Wagner, C. (2010). Cell cycle coordination and regulation of bacterial chromosome segregation dynamics by polarly localized proteins. EMBO J. 29, 3068-3081. doi: 10.1038/emboj.2010.207

Sharpe, M. E., and Errington, J. (1998). A fixed distance for separation of newly replicated copies of oriC in Bacillus subtilis: implications for co-ordination of chromosome segregation and cell division. Mol. Microbiol. 28, 981-990. doi: 10.1046/j.1365-2958.1998.00857.x

Simon, R., Priefer, U., and Puhler, A. (1983). A broad host range mobilization system for invivo genetic-engineering - transposon mutagenesis in Gramnegative bacteria. Bio Tech. 1, 784-791. doi: 10.1038/nbt1183-784

Spaink, H. P., Okker, R. J. H., Wijffelman, C. A., Tak, T., Goosenderoo, L., Pees, E., et al. (1989). Symbiotic properties of rhizobia containing a flavonoidindependent hybrid nodd product. J. Bacteriol. 171, 4045-4053. doi: 10.1128/ jb.171.7.4045-4053.1989

Sprent, J. I. (2007). Evolving ideas of legume evolution and diversity: a taxonomic perspective on the occurrence of nodulation. New Phytol. 174, 11-25. doi: 10.1111/j.1469-8137.2007.02015.x

Spurr, A. R. (1969). A low-viscosity epoxy resin embedding medium for electron microscopy. J. Ultrastruct. Res. 26, 31-43. doi: 10.1016/s0022-5320(69)90033- 1

Suzuki, S., Aono, T., Lee, K. B., Suzuki, T., Liu, C. T., Miwa, H., et al. (2007). Rhizobial factors required for stem nodule maturation and maintenance in Sesbania rostrata-Azorhizobium caulinodans ORS571 symbiosis. Applied and Environ. Microbiol. 73, 6650-6659. doi: 10.1128/aem.01514-07

Tautz, D. (1992). Redundancies, development and the flow of information. Bioessays 14, 263-266. doi: 10.1002/bies.950140410

Towbin, H., Staehelin, T., and Gordon, J. (1979). Electrophoretic transfer of proteins from polyacrylamide gels to nitrocellulose sheets: procedure and some applications. Proc. Natl. Acad. Sci. U.S.A. 76, 4350-4354. doi: 10.1073/pnas.76. 9.4350

Tsukada, S., Aono, T., Akiba, N., Lee, K.-B., Liu, C.-T., Toyazaki, H., et al. (2009). Comparative genome-wide transcriptional profiling of Azorhizobium caulinodans ORS571 grown under free-living and symbiotic conditions. Appl. Environ. Microbiol. 75, 5037-5046. doi: 10.1128/AEM.00398-09

Van De Velde, W., Zehirov, G., Szatmari, A., Debreczeny, M., Ishihara, H., Kevei, Z., et al. (2010). Plant peptides govern terminal differentiation of bacteria in symbiosis. Science 327, 1122-1126. doi: 10.1126/science.1184057

Vinardell, J. M., López-Baena, F. J., Hidalgo, A., Ollero, F. J., Bellogín, R., Del Rosario Espuny, M., et al. (2004). The effect of FITA mutations on 
the symbiotic properties of Sinorhizobium fredii varies in a chromosomalbackground-dependent manner. Arch. Microbiol. 181, 144-154. doi: 10.1007/ s00203-003-0635-3

Wake, R. G., and Errington, J. (1995). Chromosome partitioning in bacteria. Ann. Rev. Genet. 29, 41-67. doi: 10.1146/annurev.genet.29.1.41

Wang, D., Griffitts, J., Starker, C., Fedorova, E., Limpens, E., Ivanov, S., et al. (2010). A nodule-specific protein secretory pathway required for nitrogenfixing symbiosis. Science 327, 1126-1129. doi: 10.1126/science.1184096

Williams, D. R., and Thomas, C. M. (1992). Active partitioning of bacterial plasmids. J. Gen. Microbiol. 138, 1-16. doi: 10.1099/00221287-138-1-1
Conflict of Interest: The authors declare that the research was conducted in the absence of any commercial or financial relationships that could be construed as a potential conflict of interest.

Copyright $\odot 2019$ Chien, Huang, Tsai, Cheng and Liu. This is an open-access article distributed under the terms of the Creative Commons Attribution License (CC BY). The use, distribution or reproduction in other forums is permitted, provided the original author(s) and the copyright owner(s) are credited and that the original publication in this journal is cited, in accordance with accepted academic practice. No use, distribution or reproduction is permitted which does not comply with these terms. 